\title{
FAIRNESS STANDARDS AND SEPARATION AGREEMENTS: A WORD OF GAUTION ON CONTRAGTUAL FREEDOM
}

\section{SALLy BuRnetT SHaRP†}

Reconciling the principles of individualism and equality with the institution of marriage has never been an easy task. There are inherent, perhaps even irreconcilable, conflicts between the sharing and altruistic ideologies that are the foundation for the traditional family structure and the individualistic and competitive principles of the marketplace that constitute the model for most political and economic behavior outside the family. ${ }^{1}$ Nowhere are the tensions between these principles more obvious than in the continuing attempts of the law to accommodate freedom to contract, the sine qua non of a laissez-faire system, with restrictions on the ability of spouses to contract with regard to dissolution of marriage. ${ }^{2}$

At one point in the not so distant past, the law simply denied that the conflict existed at all: a wife's legal identity was "merged" into that of her husband, so that issues involving the enforceability of contracts

† Professor of Law, University of North Carolina at Chapel Hill. This project was supported by a grant from the Law Center Foundation. I wish to express my most sincere gratitude to my fine colleague and most astute critic, Professor Robert G. Byrd.

I See, e.g., Olsen, The Family and the Market: A Study of Ideology and Legal Reforms, 96 HaRv. L. REv. 1497 (1983). In her essay, Frances Olsen argues that the dichotomy between the family and the marketplace has characterized modern liberal society. Id. at 1498. Yet, as she emphasizes, these spheres of human activity have not remained separate or unrelated. The ideology of each has served as a critique of the other, and, inspired by these ideologies, the state has often intervened in each activity to make it more like its opposite. Id. at 1528. For instance, to promote the position of women the state has instituted reforms designed to allow husband and wife to contract with each other as would any two parties in the marketplace, id. at 1535-contracts that might help to break down the female subservience traditionally common in marriage, $i d$. at 1537-38. Such reforms, however, may undercut benefits of the family, such as altruism, and may not completely eradicate the inequalities already present in the family relationship. Id. at 1537-38.

${ }^{2}$ Here one must distinguish separation agreements from property settlements. A separation agreement, on the one hand, "is a contract between a husband and a wife stating that they have agreed to live separate and apart and providing for marital support rights." Sharp, Divorce and the Third Party: Spousal Support, Private Agreements, and the State, 59 N.C.L. REv. 819, 826 (1981). A property settlement, on the other hand, involves the adjustment of real and personal property rights, and it may be made at any time during marriage. Id. at 826 . For further distinctions between settlement agreements and property settlements, see 1 A. Lindey, SEparation AgreemENTS AND ANTE-Nuptial Contracts § 3, at 23-24 (rev. ed. Supp. 1983). 
executed between spouses never arose. ${ }^{3}$ By the turn of the century, however, restrictions on the nature, scope, and content of marital contracts had largely replaced the expedient of denying the wife the capacity to contract." Thus, husbands and wives were allowed to contract with one another so long as their agreements did not attempt to alter the "essential" incidents of marriage, such as the wife's right to rely on her husband for support, ${ }^{5}$ or "promote" or "encourage" divorce. Courts were particularly zealous in voiding any attempts by a husband to abrogate his duty of support. ${ }^{7}$

The public policies sought to be furthered by these restrictions on marital contracts in general and on settlement agreements in particular were somewhat varied: they included the state's interest in protecting the essential nature of marriage, ${ }^{8}$ the necessity to safeguard economically and politically disadvantaged wives from presumptively dominant husbands, ${ }^{9}$ and the desirability of preserving the home as a haven from the marketplace mentality. ${ }^{10}$ In essence, however, restrictions centered on the state's interest in maintaining the status quo of marriage, and thereby the hierarchical relationship of the parties to marriage, with the result that limitations on interspousal freedom to contract became identified with perpetuation of inequality between the sexes. ${ }^{11}$ It there-

3 Blackstone's comment is often cited as the best statement of the common law's doctrine concerning the wife's loss of legal existence during marriage: "By marriage the husband and wife are one person in law: that is, the very being or legal existence of the woman is suspended during the marriage . . . . [For a husband] to covenant with her, would be only to covenant with himself . ..." 1 W. BLACKSTONE, COMMENTARIES *430; cf. H. Clark, The Law of Domestic Relations in the United States § 7.1, at 219-21 (1968) (description of the married woman's status at common law).

- A series of state statutes, known as the Married Women's Property Acts, removed many of the disabilities that married women suffered under common law. $\mathrm{H}$. GLaRk, supra note $3, \S 7.2$, at 222 \& n.4.

- Id. at 227; cf. Sharp, supra note 2, at 822-25 (discussing the origin of the reciprocal spousal duties-the husband's duty of support and the wife's duty to render domestic services in the home).

- Sharp, supra note 2, at 831. Attempting to vary the duty of support, of course, violated both policies, so that the scope of separation agreements was in fact very limited at this point. See, e.g., Clark, Antenuptial Contracts, 50 U. Colo. L. REv. 141, 148 (1979).

7 Sharp, supra note 2, at 830-31.

8 L. Weitzman, The Marriage Contract 338 (1981).

- See id. at 344 .

10 See Olsen, supra note 1 , at 1499.

11 See Krauskopf \& Thomas, Partnership Marriage: The Solution to an Ineffective and Inequitable Law of Support, 35 OHIo ST. L.J. 558, 577, 580 (1974). This situation was somewhat ironic, since many of the restrictions on contract were designed to protect wives. Yet it has been well noted that "the principles developed to protect marriage and family as an institution are the most sex discriminatory in all of law." Id. at 558; see also Younger, Marital Regimes: A Story of Compromise and Demoralization Together with Criticism and Suggestions for Reform, 67 CoRnELL L. REv. 45, 47-48 (1981) (examining the formation of a partnership concept of marriage from common 
fore followed that the movement toward greater equality between the sexes was accompanied by demands for decreased state intervention in the regulation of marriage and divorce and in the parties' freedom to contract regarding either. ${ }^{12}$

Partly in response to such demands, and partly in response to greater changes in society and marriage, most states began to limit application of the traditional public policy restrictions on settlement agreements. Indeed, by the 1950 's such restrictions had become largely meaningless. ${ }^{13}$ States, however, did not forsake their roles as "third parties" to marriage and divorce; rather they again reaccommodated their own interests, and those of private parties, in controlling the consequences of dissolution.

In general the principle developed that spouses could contract regarding support, or any other incident of marriage, virtually without regard to whether or not such agreements tended to promote divorce, if the contracts were "fair, just and reasonable in view of all the circumstances."14 The circumstances were apt to include the possibility that the parties were involved in a confidential relationship, moreover, which imposed duties of good faith on the dominant spouse. ${ }^{18}$ The combination of this general fairness standard with the confidential relationship concept also presumed some degree of special judicial review not demanded by other types of contracts. ${ }^{16}$

Within the past two decades, however, there has been an even greater demand for a minimizing of such state intervention and for a more unfettered application of simple contract principles to marital agreements. ${ }^{17}$ In fairness, it should be noted that most of this scholar-

and civil law origins in America).

12 See Krauskopf \& Thomas, supra note 11, at 582-83 (law should cease fostering the traditional role of women); id. at 588 (proposal that all rights and legal obligations of husband and wife be subject to contractual modification).

1s Sharp, supra note 2 , at 831.

141 A. LiNDEY, supra note $2, \S 15$, at $15-91$.

15 See infra text accompanying notes 62-63.

16 See infra text accompanying notes 34-38.

17 See L. Wertzman, supra note 8, at 353-59 (arguing that the continually evolving doctrines of contract law are better equipped than family law doctrines to handle marital contracts); Gamble, The Antenuptial Contract, 26 U. MrAMI L. REv. 692, 707 (1972) (stating that "[t]he clarity of contracts in the commercial world should be available in antenuptial agreements"); Goldstein \& Gitter, On Abolition of Grounds for Divorce: A Model Statute E Commentary, 3 FAM. L.Q. 75, 92 (1969) (arguing that "[w]hen all parties, including children, are adequately represented," the court's examination of a separation agreement should be kept to a minimum "except through general doctrines of fairness in contracts such as fraud or duress"); Klarman, Marital Agreements in Contemplation of Divorce, 10 U. MICH. J.L. REF. 397, 407 (1977) (asserting that parties should be allowed to make their own agreements covering the division of property and the provision of support in the event of divorce); Krauskopf \& Thomas, 


\section{ship has focused on antenuptial agreements. ${ }^{18}$ Separation agreements,}

supra note 11, at 598 ("However, in the absence of demonstrated justification for regulation ... husband-wife relations should be determined by contract, not by operation of law."); Mnookin \& Kornhauser, Bargaining in the Shadow of the Law: The Case of Divorce, 88 YALE L.J. 950, 993 (1979) (arguing against state intervention in divorce agreements except to police manifestly unreasonable contracts); Comment, Marriage as Contract: Towards a Functional Redefinition of the Marital Status, 9 Colvm. J.L. \& SOC. PROBS. 607, 640 (1973) ("that alimony agreements are valid and conclusive unless shown to be intrinsically unfair-would be a more fruitful statutory policy, less burdensome to the divorce courts, and more harmonious with contract law in general") [hereinafter cited as Comment, Marriage as Contract]; Comment, Marital Contracts Which May Be Put Asunder, 13 J. FAM. L. 23, 45-46 (1973) (advocating contract law remedies for marital contracts, particularly those made in anticipation of divorce).

The supposition that in modern society contract rather than status should define one's social role seems to underlie the arguments for the increased application of contract principles to the marriage setting. See, e.g., Comment, Marriage as Contract, supra, at 636. This concept is, of course, attributable to Henry Maine. H. MAINE, ANCIENT LAw 165 (1970) ("[T]he movement of the progressive society has . . . been a movement from Status to Contract."). The catchy phrase is provocative, but one often wonders if it also provides an appealing excuse for the suspension of critical faculties. Moreover, one could argue that in the welfare state "status" returns in the family when the state grants spouses special rights. See Olsen, supra note 1, at 1518.

Perhaps the most extensive and persuasive argument for the use of contract principles in the marital setting is found in Shultz, Contractual Ordering of Marriage: $A$ New Model for State Policy, 70 Calif. L. Rev. 204 (1982). Professor Shultz argues that contract, with its emphasis on private choices, can best accommodate the diverse private lifestyles of modern men and women, the increased impermanence of contemporary relationships, and the individualism prevalent in them. Id. at 244-53. She states, moreover, that rational ordering assumes a great importance in relationships where individuals are concerned about their own values and needs, and that contract has proved an effective ordering device. Id. at 253-65. Professor Schultz points out that contract principles themselves have developed and become more flexible: modern contract law emphasizes enforcement and litigation less than rational planning in accordance with the choices of the parties. Id. at 305-07. Contract principles would thus better meet the needs of private relationships. For Professor Schultz, then, the state would intervene in this private contracting only to define the outer limits of unacceptable contract behavior and to maintain a fair bargaining process. Id. at 333. It should be noted, however, that Professor Schultz's article is largely devoted to the use of contracts during marriage.

${ }^{18}$ See, e.g., Clark, Antenuptial Contracts, 50 U. Colo. L. Rev. 141 (1979); see also sources cited supra note 17. The impact of such scholarship on the laws controlling antenuptial agreements has been dramatic. With the steady demise of the public policy rationale that had long prohibited parties contemplating marriage from providing for divorce contingencies, antenuptial contracts have become functionally indistinguishable from separation agreements in many ways. This conclusion was drawn somewhat tentatively by Clark. See Clark, supra, at 150 . The rapidly growing number of states that now at least allow provision for property rights in contemplation of divorce makes the conclusion inescapable. See Newman v. Newman, 653 P.2d 728 (Colo. 1982); Parniawski v. Parniawski, 33 Conn. Supp. 44, 359 A.2d 719 (Super. Ct. 1976); Burtoff v. Burtoff, 418 A.2d 1085 (D.C. 1980); Scherer v. Scherer, 249 Ga. 635, 292 S.E.2d 662 (1982); Volid v. Volid, 6 Ill. App. 3d 386, 286 N.E.2d 42 (1972); Tomlinson v. Tomlinson, 170 Ind. App. 331, 352 N.E.2d 785 (1976); Osborne v. Osborne, 1981 Mass. Adv. Sh. 2216, 428 N.E.2d 810; Hatner v. Hatner, 295 N.W.2d 567 (Minn. 1980); Freeman v. Freeman, 565 P.2d 365 (Okla. 1977); Unander v. Unander 265 Or. 102, 506 P.2d 719 (1973); Friedlander v. Friedlander, 80 Wash. 2d 293, 494 P.2d 208 (1972). 
unfortunately, have tended to be swept into both the argument and the conclusion that marital contracts should, in general, be accorded the same judicial treatment as any other contract. ${ }^{19}$ The "any other contract" advocates, moreover, would also appear to assume that broad changes in society, in equality between the sexes, and in the substantive law of contracts have rendered the traditional protective system both obsolete and offensive. ${ }^{20}$ In particular, these scholars tend to regard judicial review as an unnecessary vestige of a paternalistic legal system that simultaneously creates undue opportunities for excessive subjectivity in the exercise of judicial discretion and undermines the reasonable expectations of the parties in the finality of their agreements. ${ }^{21}$

Not everyone has climbed aboard this increasingly crowded and largely well-intentioned bandwagon, and there are occasional calls for greater state supervision of marital contracts. ${ }^{22}$ A recognition of the

Unfortunately, standards governing the execution of antenuptial agreements are considerably more straightforward, and often more sensible, than those of separation agreements. In addition to being untainted by fraud, duress, or undue influence, an antenuptial contract that provides for divorce must meet several other requirements.

On the one hand, it should make an adequate provision for the less experienced party, considering his or her needs and the other's means. Clark, supra, at 145. If the agreement fails to make such a provision, then the other party will be required to demonstrate that the agreement was based on full disclosure of his or her assets. Id. Yet if the less experienced party is fully advised of his or her rights or if he or she is experienced in business and financial affairs, a lack of disclosure will not invalidate an agreement. Id. A key element in the court's determination whether to uphold such agreements is this party's opportunity to obtain independent counsel. See id. at 146. Some notion of the extent to which such agreements are reviewed for fairness is provided by a Florida court of appeals: "Where one party has overreached the other and gained an unjust and undeserved advantage which would be inequitable to enforce, the courts may refuse to enforce the agreement even though the victimized parties owe their predicament largely to their own stupidity and carelessness." Carnell v. Carnell, 398 So. 2d 503, 506 (Fla. Dist. Ct. App. 1981) (citation omitted).

Homer Clark has aptly noted the paradox that the "effort to give the spouses greater control over their marriage should result in a broader state regulation of the relationship than ever before in our history." Clark, supra, at 162-63. It should also be noted that the same standards are in some instances applied to both antenuptial and separation agreements. See Osborne v. Osborne, 1981 Mass. Adv. Sh. 2216, 428 N.E.2d 810; Buettner v. Buettner, 89 Nev. 39, 505 P.2d 600 (1973); Davis v. Davis, 24 Ohio Misc. 17, 258 N.E.2d 277 (C.P. Mahoning County 1970); Ratony Estate, 443 Pa. 454, 277 A.2d 791 (1971).

19 See, e.g., L. WEITZMAN, supra note 8, at 354-356; Owen v. Owen, 427 A.2d 933 (D.C. 1981); Lane v. Scarborough, 284 N.C. 407, 200 S.E.2d 622 (1973). Indeed, there has been little painstaking analysis of the very real differences between the two types of marital contracts. But see discussion infra note 29.

${ }^{20}$ See L. Wertzman, supra note 8, at xix-xxi; Mnookin \& Kornhauser, supra note 17 , at 993 . The more fundamental problem, however, may be that the system was simply ineffective. See infra text accompanying notes 60-97.

${ }_{22}$ See L. WeItzMan, supra note 8 , at $\mathrm{xx}-\mathrm{xxi}, 353-54$; Krauskopf \& Thomas, supra note 11, at 598 .

${ }^{22}$ See, e.g., Haskell, The Premarital Estate Contract and Social Policy, 57 N.C.L. REv. 415 (1979). Professor Haskell's position originates from two concerns: 
unique opportunities for fraud and overreaching that exist between a husband and wife, moreover, has led often to the caveat that increased freedom to contract can occur only against a "backdrop of fair standards." 23 This approach sometimes includes an appreciation of the desirability of judicial review for fairness but more often assumes that procedural safeguards derived from traditional and developing contract principles, ${ }^{24}$ and especially those derived from the confidential relationship, are adequate to protect against unfair bargaining conduct. This approach, therefore, would not countenance the varieties of fraud and overreaching to which the traditional protective system was partly a response in the first instance. Rather, the argument, as developed most ably by Professor Weitzman, is that evolving contract principles controlling the negotiation process have created "the doctrinal tools necessary to handle problems of fraud or unconscionability that may arise in antenuptial or postnuptial agreements."25

It is possible to view the distinction between a system that creates

that many married women are still financially dependent upon their husbands and thus need state protection, $i d$. at 426 , and that if parties could contract away support duties or other responsibilities marriage would become an empty institution, id. at 428 . See also Rheinstein, Division of Marital Property, 12 WILLAMETTE L.J. 413 (1976) (advocating judicial supervision of marital contracts, both antenuptial and separation). Professor Rheinstein admits that parties should be able to agree "that there will not be judicial modification of the property or maintenance terms of a divorce decree or of a separation agreement except in extreme circumstances of unconscionability at the time of the original determination." Id. at 438; cf. Clark, supra note 18, at 151 (antenuptial agreement should be enforced only if fair both at the date of execution and the date of performance).

${ }^{28}$ Mnookin \& Kornhauser, supra note 17, at 957. In arguing for more private ordering of marital life, Professors Mnookin and Kornhauser do not dismiss judicial review of such agreements. Although they are somewhat dubious of the value of such review, their more fundamental objection is that requiring judicial review in all divorce cases is a waste of judicial resources. It also distorts the process of judicial review so that cases that do need special attention are apt not to be identified. Id. at 993 . The authors do suggest that "[a] better system would define, within a broad range, the norms that should govern divorce agreements and use those norms to identify for intensive judicial scrutiny the cases falling outside what is ordinarily thought reasonable. Cases settled within the normal range would require no prior review at all." Id. They do not provide any guidelines for these norms, however. See infra notes 242-262 and accompanying text.

24 See L. WertzmaN, supra note 8, at 353; Schultz, supra note 17, at 293-94.

25 L. Weitzman, supra note 8, at 346. Professor Weitzman relies largely on the unconscionability concept as a remedy for bad faith bargaining. Id. at 344-46; cf. infra text accompanying notes 212-15. (arguing that one cannot equate unconscionability with a genuine substantive fairness test). In general, however, she appears to assume that spouses will usually bargain in good faith, L. WeITZMAN supra note 8, at 359-an assumption that, at least with settlement agreements, is questionable. See infra text accompanying notes 108-12. Professor Shultz also emphasizes that unconscionability, a model of the new flexible contractual principles that encourage courts to examine the execution of an agreement, would serve well to regulate marital contracts. See Shultz, supra note 17 , at 294. 
a "special" body of contract law for domestic relations and one wherein expanding contract principles can deal effectively with the "special" problems of domestic law merely as a difference in means aimed at the same general goal of fairness. But the distinction is nonetheless critical if standard contract principles provide inadequate protection, if courts are unable or unwilling to develop and use the doctrinal tools necessary to guard against unfair bargaining practices, and if greater freedom to contract results in greater judicial tolerance for the marketplace mentality in marriage dissolution. ${ }^{26}$

It is the premise of this Article that the existence of contract standards necessary to ensure creation of the kind of arm's length agreements deserving "any other contract" treatment, and of procedures adequate to provide relief from unconscionable or fraudulently procured contracts, has been too readily assumed. Indeed, at least at a practical level, contract principles, centering as they do largely on the process and not the result of bargaining, cannot bear such a burden. In any event, contract doctrines, even including unconscionability, have often failed to provide adequate safeguards in the family law setting against either unfair results or unfair procedures. ${ }^{27}$ The same criticism, however, is equally applicable to the existing system of mixed substantive and procedural standards: procedural standards are often woefully inadequate, and meaningful review of settlement agreements for substantive fairness rarely occurs.

The conclusion that both procedural and substantive standards are frequently inadequate to ensure fairness in settlement agreements clearly assumes that fairness in results is an appropriate goal. While this assumption is open to objections, which will be treated in a later portion of this Article, ${ }^{28}$ it rests fundamentally upon the conclusion that separation agreements are different from other kinds of contracts, including even antenuptial contracts. ${ }^{29}$ They deal with issues of custody,

${ }^{28}$ It is in fact likely that this has already occurred. Frances Olsen has concluded that "[t]he liberalization of the family was marked by shifts toward equal juridical rights and the withdrawal of the state. This trend has continued to the present, with the family coming to assume more of the characteristics associated with the free market." Olsen, supra note 1, at 1517. Yet she points out that just as the state has intervened in the market and singled out people, such as employees, for special treatment, so also has it regulated the family. Id. at 1515-18.

27 See infra notes $213-15$ and accompanying text.

28 See infra notes 231-64 and accompanying text.

19 In re Marriage of Manzo, 659 P.2d 669 (Colo. 1983), is one of the few decisions that deal adequately with the distinctions between separation and antenuptial agreements. Although the supreme court upheld a property settlement agreement against a challenge by a husband, it called for a high standard of review with these contracts:

[W]e conclude that before a court incorporates property division provisions 
support, and property division that are of paramount significance to the individuals involved and to society. They are negotiated under conditions of extraordinary stress by parties unusually susceptible to what Arthur Leff called "bargaining naughtiness," to exploit psychological and emotional dependencies built up over a period of years. They are also negotiated within the context of a "market," dissolution of marriage, that deviates substantially from the competitive, arm's length bargaining between strangers in which standard bargaining principles were designed to operate. To the degree, moreover, that settlement agreements result in unfair distributional consequences, they are glaringly inconsistent with the sharing principles that underlie the very essence of the marital relationship. ${ }^{31}$ Such unfair results also create embittered, if not impoverished, spouses, who in turn create an almost geometric increase in the difficulties experienced by

of a separation agreement into a dissolution decree, it should first review the provisions for fraud, overreaching, concealment of assets, or sharp dealing not consistent with the obligations of marital partners to deal fairly with each other, and then look at the economic circumstances of the parties which result from the agreement, including a determination whether under the totality of the circumstances the property disposition is fair, just and reasonable.

Id. at 674 (footnote omitted). Moreover, it distinguished this standard from that applicable to antenuptial agreements:

Courts reviewing separation agreements prior to entry of a decree of dissolution need more latitude than is allowed for review of antenuptial agreements because of the public policy concern for safeguarding the interests of a spouse whose consent to the agreement may have been obtained under more emotionally stressful circumstances, especially if that spouse is unrepresented by counsel.

Id. at 675 (citations omitted). The court reasoned, quite accurately, that parties to separation agreements are in fact more vulnerable to overreaching than are parties to antenuptial agreements. Id.; see also Newman v. Newman, 653 P.2d 728, 733 (Colo. 1982).

Most courts, however, would agree with the remarks of the Massachusetts Supreme Court that the public policies are the same "whether the agreement is entered into before the marriage or after the marriage and in expectation of separation or divorce." Osborne v. Osborne, 1981 Mass. Adv. Sh. 2216, 428 N.E.2d 810, 816; see also cases cited supra note 18.

It is well recognized that separation agreements are different from other types of nonmarital contracts. See, e.g., Spector v. Spector, 23 Ariz. App. 131, 531 P.2d 176 (1975); Glatterbaugh v. Clatterbaugh, 182 Neb. 160, 163, 153 N.W.2d 749, 752 (1967); Christian v. Christian, 42 N.Y.2d 63, 365 N.E.2d 849, 396 N.Y.S.2d 817 (1977). Few, however, would go so far as the court in Lepis v. Lepis, 83 N.J. 139, 148, 416 A.2d 45, 50 (1980) ("contract principles have little place in the law of domestic relations").

so Leff, Unconscionability and the Code - The Emperor's New Clause, $115 \mathrm{U}$. PA. L. REv. 485, 539 (1967).

31 Prager, Sharing Principles and the Future of Marital Property Law, 25 UCLA L. REv. 1, 5-6 (1977) (arguing that marital property law should reflect the sharing principles that infuse modern marriage). 
the children of divorce. ${ }^{32}$

This Article will first attempt to identify and criticize the existing standards governing the execution and enforceability of separation and property settlement agreements. It will demonstrate that in a surprisingly large number of states there exist inadequate standards, both procedural and substantive, to ensure that only fair agreements receive judicial approval. It will argue further that the confidential relationship concept has provided an insufficient foundation for the imposition of meaningful disclosure duties and that the law of fraud, undue influence, and duress is, at least in a domestic law context, inadequately developed to provide protection against some common forms of unfair bargaining techniques. The Article will then demonstrate that the courts rarely apply a substantive standard of review to settlement agreements and that their doctrinal tools, such as unconscionability, do not insure a meaningful analysis of the substance of the contract terms. It will conclude with an argument that fair results can be guaranteed only by imposition of meaningful substantive review standards and will respond to objections to use of such standards. Finally, it will suggest the development of guidelines by which genuine judicial review for substantive fairness may be more easily undertaken.

\section{General Standards and Judictal Review}

Existing restrictions on parties' freedom to determine for themselves the distributional consequences of divorce are aimed primarily at ensuring that the process, if not the result, of private contracting is fair. Thus it is commonly said that a settlement agreement, like any other contract, must be free from any fraud, duress, undue influence, or over-

22 To a remarkable extent, it appears that divorced women, especially those with children, are often impoverished. See Weitzman, The Economics of Divorce: Social and Economic Consequences of Property, Alimony and Child Support Awards, 28 UCLA L. REv. 1181, 1252-53 (1981). That divorced men often refuse to comply with support agreements only partially accounts for this impoverishment. Id. at 1253-54. While it is likely that the cases that form the basis for this Article reflect generally higher socioeconomic groups than those which formed the basis for Professor Weitzman's excellent study, the disparity in the relative standards of living of the parties after divorce would probably remain the same. In fact, her statistics demonstrate that in higher income bracket families $(\$ 40,000+)$ women will often have after divorce a much smaller percentage of the family's former income than would women from lower income families. Id. at 1243-46. As Professor Weitzman points out, "it is the discrepancy between the postdivorce standards of living, especially among middle-class and uppermiddle-class couples, that fosters much of the feeling of injustice expressed by so many women after divorce." Id. at 1246.

A drastically lowered economic status, moreover, clearly increases the already traumatic effect of divorce upon children. See Watson, The Children of Armageddon: Problems of Custody Following Divorce, 21 SyRacuSE L. REv. 55 (1969-70). 
reaching of any kind. ${ }^{33}$ Most states, however, impose as an additional safeguard the requirement that an agreement be submitted to a court for its approval and that it cannot be merged or incorporated into the final decree without such approval. ${ }^{34}$ Judicial approval, at least in theory, will be withheld unless the court finds that the proposed agreement is equitable, or fair and reasonable, ${ }^{35}$ or not unconscionable. ${ }^{36}$ In other states some degree of fair dealing may also be imposed by statutes that subject all husband-wife contracts, including settlement agreements, to the rules governing the conduct of persons in confidential relationships. ${ }^{37}$ There is also a sizeable body of case law in several states,

3s 1 A. LINDEY, supra note $2, \S 3$, at 3-21.

34 Terms such as "merger" and "incorporation" have long been a source of hopeless confusion in family law. See Sharp, supra note 2, at 848-50. For present purposes, however, the terms refer to whatever means by which an agreement between the parties becomes a judgment.

36 See Gonn. Gen. Stat. AnN. § 46b-66 (West Supp. 1982) (court must determine if the agreement is "fair and equitable under all the circumstances"); HAwaII REv. STAT. § 573-2 (1976) (requiring court approval for any support agreement, which is always modifiable); IND. CoDE ANN. \$ 31-1-11.5-10 (Burns 1971) (requiring court approval before incorporation into decree); Kan. STAT. ANN. \$ 60-1610(b)(3) (Supp. 1981) (court must find agreement to be "valid, just and equitable" before incorporation); WIS. STAT. ANN. \$ 767.255(11) (West 1981) ("no such agreement shall be binding where the terms of the agreement are inequitable as to either party"). If a court refuses to accept the parties' agreement, as a result either of a party's objections or of its own inquiries, it may devise its own order or require the parties to negotiate a new agreement more acceptable to the bench. See, e.g., Lewis v. Lewis, 4 Kan. App. 2d $165,169,603$ P.2d 650, 653 (1979) ("A necessary corollary of the trial court's duty to examine a separation agreement as to whether it is valid, just and equitable, is the power to modify such agreement prior to its incorporation into the decree."); UNIF. MARRIAGe and Divorce ACT \$ 306(c), 9A U.L.A. 136 (1973) ("If the court finds the separation agreement unconscionable, it may request the parties to submit a revised separation agreement or may make orders for the disposition of property, maintenance, and support.").

${ }_{36}$ This is the standard of the UNIF. Marriage AND Divorce Act $\S 306(c), 9 \mathrm{~A}$ U.L.A. 136 (1973); see also Colo. Rev. STAT. § 14-10-112(2) (1973); Marriage \& Dissolution Act $\S 502(b)$, Ill. ANN. STAT. ch. $40 \S$ 502(b) (Smith-Hurd 1980); Ky. Rev. Stat. § 403.180(2) (Supp. 1982); Mont. Code ANN. § 40-4-201(2) (1983); Neb. REv. STAT. § 42-366(2) (Supp. 1982). Unconscionability is discussed in considerably more detail infra notes 208-15 and accompanying text. Clearly, however, the standard envisions a review for substantive as well as procedural fairness. The degree to which courts actually undertake such review is, of course, often extremely limited. See, e.g., Mnookin \& Kornhauser, supra note 17, at 954 (court review "appears to be largely perfunctory"); Rheinstein, supra note 22, at 437 ("the extent to which a separation agreement will actually be scrutinized by the judge of an overcrowded divorce court on his own motion is dubious").

s7 See, e.g., Ala. Code § 30-4-9 (1983); Cal. Civ. Code § 5103 (West 1970), which subjected husband and wife transactions to the rules of confidential relationships but has been replaced by GAL. Civ. CoDe $\S 5125$ (e) (West 1983) (effective July 1 , 1983), which requires that "[e]ach spouse shall act in good faith with respect to the other spouse in the management and control of the community property"; NEv. REv. STAT. $\$ 123.070$ (1979); N.M. STAT. ANN. § 40-2-2 (1978); OhIo Rev. Code ANN. § 3103.05 (Page 1980); OkLA. Stat. ANN. tit. 32, $\$ 5$ (West 1976). In addition, case 
whose statutes otherwise appear to be silent on the issue, requiring that separation agreements be fair, reasonable, and untainted by fraud. ${ }^{38}$

Before an erroneous impression of the efficacy of judicial review standards is created, however, two points, both of which will be treated in considerable detail later in this Article, ${ }^{\mathbf{3 9}}$ must be made clear. First, these enunciated fairness standards are often interpreted very narrowly: they may well look solely to the process of contracting, with little or no regard to the ultimate fairness of the agreement. ${ }^{40}$ Thus what appears to be a substantive review standard is often a procedural standard only. At a minimum, these "fairness" standards are so vague that they tell us very little about the characteristics of an agreement, or the factual circumstances surrounding its execution, that will render it enforceable or not.

Second, judicial review requirements as currently applied by courts fail in any event to provide a meaningful review for either substantive or procedural fairness. The review process is almost wholly perfunctory in most states. ${ }^{41}$ Although courts are usually free to "approve and adopt the agreement, reject it entirely, or modify it as the facts and circumstances may warrant," ${ }^{242}$ it is extremely rare for a court

law in several states creates a strong presumption of a confidential relation between husband and wife. See, e.g., Blaising v. Mills, 176 Ind. App. 141, 147, 374 N.E.2d 1166, 1170 (1978); Daffin v. Daffin, 567 S.W.2d 672, 678 (Mo. Ct. App. 1978); Christian v. Christian, 42 N.Y.2d 63, 72, 365 N.E.2d 849, 855, 396 N.Y.S.2d 817, 823 (1977); Link v. Link, 278 N.C. 181, 193, 179 S.E.2d 697, 704 (1971); Marshall v. Marshall, 273 S.E.2d 360, 362 (W. Va. 1980). Confidential relationship duties often do not extend to husbands and wives who are negotiating a separation agreement, however. See infra text accompanying notes 78-82.

See, e.g., Baker v. Baker, 394 So. 2d 465 (Fla. Dist. Ct. App.), cert. denied, 402 So. 2d 607 (Fla. 1981); Carlsen v. Carlsen, 72 N.J. 363, 371 A.2d 8 (1977); Eubanks v. Eubanks, 273 N.C. 189, 159 S.E.2d 562 (1968); Marriage of Bach, 27 Or. App. 421, 555 P.2d 1264 (1976); Drawdy v. Drawdy, 275 S.C. 76, 268 S.E.2d 30 (1980). On the other hand, see Bell v. Bell, 38 Md. App. 10, 14, 379 A.2d 419, 422 (Ct. Spec. App. 1977) (citations omitted), where the court concluded that agreements set aside as "unjust or inequitable on their face" were only those "completely lacking in any reasonable consideration."

so See infra text accompanying notes 192-230.

10 See, e.g., infra text accompanying notes 204-09. For example, in Reynolds v. Reynolds, 415 A.2d 535 (D.C. 1980), the court upheld an agreement because no evidence of procedural unfairness, whether "fraud, duress, concealment or overreaching," appeared on the record. Id. at 537. Yet the court pointed out that the husband challenging the agreement did receive consideration from it, id., and that this would "preclude the voiding of the Agreement here on the ground it was unfair and unreasonable on its face," $i d$. at 537 n.5 (citations omitted).

41 See Mnookin \& Kornhauser, supra note 17, at 993.

42 Wick v. Wick, 107 Ariz. 382, 385, 489 P.2d 19, 22 (1971). See also Kohn v. Kohn, 52 Ala. App. 636, 296 So. 2d 725 (1974); Olsher v. Olsher, 78 Ill. App. 3d 627, 397 N.E.2d 488 (1979); Flora v. Flora, 166 Ind. App. 620, 337 N.E.2d 846 (1975); Diers v. Diers, 185 Neb. 552, 177 N.W.2d 503 (1970); Peterson v. Peterson, 85 N.J. 638, 428 A.2d 1301 (1981); Scanlon v. Scanlon, 60 N.M. 43, 287 P.2d 238 (1955); 
to undertake sua sponte any review that would result in modification of any proposed agreement.

This all too common failure to conduct meaningful reviews for either substantive or procedural fairness is unfortunate in itself, since it creates a largely illusory safeguard. It has an even more unfortunate and ironic effect, however, in that the full range of res judicata consequences attach to an agreement merged or incorporated into a decree whether or not it received meaningful review by a court. ${ }^{43}$ Thus the judicial review requirement not only fails to create adequate safeguards against unfairness but also undermines the very fairness goals it was designed to further in the first instance, by imposing significantly increased burdens required to set aside a decree. ${ }^{44}$

The types of unfair bargaining practices that will lead a court to set aside an agreement prior to divorce, or to set aside a decree based upon such agreement, are often similar. ${ }^{45}$ The distinction between the

Forcucci v. Forcucci, 83 A.D.2d 169, 443 N.Y.S.2d 1013 (1981); Seelig v. Seelig, 460 P.2d 433 (Okla. 1969); In re Marriage of Frey, 23 Or. App. 25, 541 P.2d 145 (1975); Perry v. Perry, 183 Tenn. 362, 192 S.W.2d 830 (1946); Naylor v. Naylor, 563 P.2d 184 (Utah 1977); Bliwas v. Bliwas, 47 Wis. 2d 635, 178 N.W.2d 35 (1970). In some states, on the other hand, courts are bound to accept agreements submitted to them by the parties, absent some finding of unconscionability or overreaching. See, e.g., In re Marriage of Deines, 41 Colo. App. 98, 608 P.2d 375 (1980) (separation agreement binding absent finding of unconscionability or of proof that written agreement did not express the true intent of the parties); Zakoor v. Zakoor, 240 So. $2 d 193$ (Fla. Dist. Ct. App. 1970); In re Marriage of Lorenzi, 84 Ill. App. 3d 427, 405 N.E.2d 507 (1980); Jackson v. Jackson, 571 S.W.2d 90 (Ky. Ct. App. 1978); Merritt v. Merritt, 616 S.W.2d 585 (Mo. Ct. App. 1981); Tureman v. Tureman, 620 P.2d 1200 (Mont. 1980); Morgan v. Morgan, 622 S.W.2d 447 (Tex. Civ. App. 1981).

43 This, however, is not always the case. In New Jersey, where separation agreements are enforceable only in equity, not at law, that an agreement has been incorporated into a judgment has been said to be "of no particular importance." Carlsen v. Carlsen, 72 N.J. 363, 371, 371 A.2d 8, 12 (1977).

4t It is interesting to note that in a very similar situation some courts, in effect, have created a significantly less burdensome res judicata standard with consent decrees. See Sharp, Modification of Agreement-Based Custody Decrees: Unitary or Dual Standard?, 68 VA. L. REV. 1263 (1982). In that article I argued against imposition of a lesser standard for modification of agreement-based custody decrees. The thrust of that piece, however, was that the best interests of the child were ill-served by a rule that allowed parents to sue for custody modifications based upon facts that existed, but were not made known to the court, at the time it approved an initial custody agreement. $I d$. at 1289 . The rationale used in the cases formulating such a rule-that because issues had not been actually raised before or determined by a court, a more restrained application of res judicata principles was appropriate, $i d$. at 1266-71-does have some merit in this context. Surprisingly, only one case has alluded to this possibility: in Brennan v. Brennan, 124 Cal. App. 3d 598, 604, 177 Cal. Rptr. 520, 525 (1981) (extrinsic fraud where wife relied on representations of husband and his lawyer), the court based a finding of extrinsic fraud in part on the fact that "[ $t]$ here was no meaningful judicial time invested in trial of a cause or an issue," since the decree approving the separation agreement had been entered by consent.

45 Fraud, misrepresentation, failure to disclose, duress, and undue influence, the 
burden of proof confronting a party who seeks to have an agreement or a part thereof set aside prior to merger or incorporation into a final decree and the burden imposed in order to reopen or set aside a decree, however, is critical. In the former instance he or she must allege sufficiently unfair bargaining practices or results to persuade a court to exercise its discretion to reject or set aside the agreement; in the latter, he or she must prove that such unfair practices constitute actual fraud. ${ }^{\mathbf{4}}$ In many and possibly even most cases, however, victims of unfair bargaining practices do not discover potential grounds for relief from an improperly procured and improvidently executed agreement until after a decree has been entered and the time for appeal has passed. This is virtually always the case, for instance, with misrepresentation and concealment of, or failure to disclose, marital or community property, probably the single most frequent form of unfair bargaining conduct. ${ }^{47}$

In most states it is possible to move for the reopening of a judgment within a certain period of time after it is rendered, usually by means of a Rule 60 (b) motion or the state equivalent. ${ }^{48}$ Often the time for obtaining such relief by motion is short, ${ }^{49}$ however, and a party seeking the motion must prove, in nearly all domestic cases, that the judgment was procured by fraud. ${ }^{50}$ The standard is, of course, unobjec-

most common allegations of misconduct, are discussed in later sections of this Article. See infra text accompanying notes 106-91.

16 Compare H. ClaRK, supra note $3, \S 16.2$, at 523-25 (examination of a separation agreement by a court before incorporation with the divorce decree) with id. $\S$ 16.15, at 566-71 (judicial review after incorporation).

17 See infra note 112.

48 FED. R. Crv. P. 60(b) provides for relief from judgment for reasons of "(1) mistake, inadvertence, surprise, or excusable neglect; (2) newly discovered evidence which by due diligence could not have been discovered in time to move for a new trial ... (3) fraud (whether heretofore denominated intrinsic or extrinsic), misrepresentation, or other misconduct of an adverse party . . . ." Subsection (3) is the major means for relief from judgment in domestic law cases. For state laws containing identical or substantially similar provisions, see Al.A. R. Civ. P. 60(b) (time limit of four months); ARIz. R. Grv. P. 60(c) (six months); Colo. R. CIv. P. 60(b) (six months); DeL. GH. Ct. Rule 60 (b) (one year); Fla. R. Grv. P. 1.540(b) (one year); Idaho R. Grv. P. 60(b) (six months); IND. T.R. 60(B) (one year); KaN. R. Crv. P. 60-260(b) (one year); Mass. Grv. R. 60(b) (one year); MiCH. G.C.R. 528.3 (one year); MrNN. R. Crv. P. 60.02 (one year); MoNT. R. Grv. P. 60(b) (180 days depending on method of service); Nev. R. CIV. P. 60(b) (six months); N.M. R. Giv. P. 60(b) (one year); N.D. R. Giv. P. 60(b) (one year); OHIo Giv. R. 60(b) (one year); R.I. R. Crv. P. 60(b) (one year); S.D. R. Giv. P. 15-6-60(b) (one year); TENN. R. Giv. P. 60.02 (one year); Utah R. Crv. P. 60(b) (three months); VT. R. Crv. P. 60(b) (one year); WASH. Rev. Code ANN. § 4.72 .080 (1982); W. VA. R. Grv. P. 60(b) (eight months); Wyo. R. Giv. P. 60(b) (one year).

10 See supra note 48.

so For a discussion of misrepresentation of assets and fraud, see infra note 112. An agreement will occasionally be set aside on the grounds of mutual mistake. See In re Marriage of Deines, 41 Colo. App. 98, 608 P.2d 375 (1980). More often, however, the opposite result obtains. See, e.g., Higby v. Higby, 558 P.2d 493 (Colo. App. 1975); 
tionable in itself: principles of finality require that there be limited opportunities to relitigate real or imagined wrongs. In practice, however, the definition of fraud in this context is often limited, and bargaining tactics that are the very antithesis of good faith may nonetheless fail to constitute actual fraud. ${ }^{\mathbf{5 1}}$ Most importantly, failure to disclose marital assets may fall outside the definition of fraud. ${ }^{\mathbf{2}}$

When the misrepresentation or other fraudulent conduct is not discovered until the time for relief by motion has passed, relief will normally be available only through an independent action in equity to have the judgment set aside. Traditionally, the independent equity action requires proof not merely of fraud but of extrinsic fraud as well. ${ }^{\text {ss }}$ The results of imposing this burden of proof are harsher yet: even the most flagrant and outrageous misrepresentations of marital assets, for instance, will often be held to constitute simple intrinsic fraud and so will not provide a basis for relief. ${ }^{54}$

Fortunately, many courts have begun to mitigate some of the more

Harder v. Harder, 49 Or. App. 582, 619 P.2d 1367 (1980); Damstra v. Starr, 585 S.W.2d 817 (Tex. Civ. App. 1979) (unilateral mistake).

51 See cases cited infra note 54; see also Unser v. Unser, 86 N.M. 648, 526 P.2d 720 (1974) (in a Rule 60(b) action to set aside a property settlement, court decided that husband's promises to remarry wife if she agreed to settlement did not constitute fraud). Sometimes the reverse is also true. Acts that would not constitute classic fraud may nonetheless receive that characterization, even under Rule 60(b). See 2 A. LiNDEY, supra note 2, § 37, at 37-11. See also Christian v. Christian, 42 N.Y.2d 63, 71-72, 365 N.E.2d 849, 855, 396 N.Y.S.2d 817, 824 (1977): "Equity is so zealous in this respect that a separation agreement may be set aside on grounds that would be insufficient to vitiate an ordinary contract . . . Facts giving rise to relief under a Rule 60 (b) motion will often suffice to provide relief in an independent equity action; the definition of fraud in both contexts, therefore, is often quite similar.

${ }^{82}$ See infra note 117 and accompanying text.

ss See, e.g., Brennan v. Brennan, 124 Cal. App. 3d 598, 177 Cal. Rptr. 520 (1981); Kulchar v. Kulchar, 1 Gal. 3d 469, 462 P.2d 17, 82 Cal. Rptr. 489 (1969); Berg v. Berg, 227 Minn. 173, 34 N.W.2d 722 (1948); Daffin v. Daffin, 567 S.W.2d 672 (Mo. Ct. App. 1978); Hopper v. Hopper, 183 Mont. 543, 601 P.2d 29 (1979); Moore v. Moore, 78 Nev. 186, 370 P.2d 690 (1962); Amar v. Amar, 589 P.2d 237 (Okla. Ct. App. 1978); McFarland v. Reynolds, 513 S.W.2d 620 (Tex. Civ. App. 1974). For a good discussion on the origins of this troublesome distinction between intrinsic and extrinsic fraud, see St. Pierre v. Edmonds, 645 P.2d 615, 618-19 (Utah 1982) (extrinsic fraud found when husband's threats of bodily harm forced wife to sign a settlement agreement and prevented her from contesting it). Fraud is extrinsic or collateral when it "prevents a party from having a trial, or from representing all of his case to the court, or which operates, not upon matters pertaining to the judgment itself, but to the manner in which it is procured." Dockery v. Central Ariz. Light \& Power Co., 45 Ariz. 434, 450, 45 P.2d 656, 663 (1935). Fraud is intrinsic when it "refers to matters occurring during the course of the proceedings, such as false testimony during the trial, which may have influenced the judgment." St. Pierre, 645 P.2d at 618 (citations omitted).

s4 See, e.g., Miller v. Miller, 616 P.2d 313 (Mont. 1980); Rylee v. McMorrough, 616 S.W.2d 649 (Tex. Giv. App. 1981); Clissold v. Clissold, 30 Utah 2d 430, 519 P.2d 241 (1974), overruled by St. Pierre v. Edmonds, 645 P.2d 615 (Utah 1982). 
severe consequences of the traditional rule by stretching the definition of extrinsic fraud to include almost any species of fraud, ${ }^{\mathrm{bS}}$ by finding that a fraud has been perpetrated on the court, ${ }^{56}$ or by discarding the distinction altogether. ${ }^{57}$ As the Supreme Court of Utah recently concluded, the intrinsic/extrinsic fraud distinction does indeed "fail to provide a rational basis for the harsh consequences that flow from it." Even in those states that have rejected the distinction, however, a clearer and more compelling showing of fraud will nonetheless be required for the independent equity action. ${ }^{59}$

The basic point, however, is that perfunctory judicial review of settlement agreements undoubtedly does more harm than good. Certainly any reliance on it to ensure fairly procured or substantively fair agreements would be misplaced. To a lesser but still significant degree, the same conclusion may be drawn with respect to the second major safeguard of the existing system of fairness standards, the confidential

ss See, e.g., Hood v. Hood, 335 F.2d 585 (10th Cir. 1964) (misrepresentation as extrinsic fraud); Bates v. Bates, 1 Ariz. App. 165, 169, 400 P.2d 593, 597 (1965) (misrepresentation of assets prevented a "fair submission of the controversy" and thus constituted extrinsic fraud); Brennan v. Brennan, 124 Cal. App. 3d 598, 177 Cal. Rptr. 520 (1981) (holding misrepresentations of husband and his attorney to wife to be extrinsic fraud); Parke v. Parke, 72 Idaho 435, 242 P.2d 860 (1952) (concealment of assets as extrinsic fraud); Daffin v. Daffin, 567 S.W.2d 672 (Mo. Ct. App. 1978) (inducement of wife to forego advice of counsel held to be extrinsic fraud); Pilati v. Pilati, 181 Mont. 82, 592 P.2d 1374 (1979) (husband's extraordinary "nondisclosures" held to be extrinsic fraud).

s8 In Roth v. Roth, 45 Ill. 2d 19, 256 N.E.2d 838 (1970), for instance, the court held that a wife's misrepresentation of plans to remarry after the divorce was a fraud upon the court. In Allen v. Allen, 341 Mich. 543, 67 N.W.2d 805 (1954), a wife's concealment of her pregnancy by another man was similarly found to be fraud upon the court.

s7 See Compton v. Compton, 101 Idaho 328, 612 P.2d 1175 (1980); St. Pierre v. Edmonds, 645 P.2d 615 (Utah 1982); cf. H. GLARK, supra note 3, $§ 16.15$, at 566-70 (discussion of a general fraud standard in family law cases that abandons the extrinsic/ intrinsic distinction).

ss St. Pierre v. Edmonds, 645 P.2d 615, 619 (Utah 1982). The traditional distinction, concluded one writer, "is unnecessary, often irrational, and potentially productive of injustices not outweighed by the interests of finality." Comment, Rule 60(b): Survey and Proposal for General Reform, 60 CaLIF. L. Rev. 531, 542 (1972). This is particularly true with family actions, moreover, since agreement-based decrees are almost by definition entered by consent. Further, as a California court observed in Brennan v. Brennan, 124 Cal. App. 3d 598, 604, 177 Cal. Rptr. 520, 523-24 (1981), "where there has been little or no judicial time invested in trial of a cause or an issue, the factor of judicial economy which otherwise weighs in favor of finality is less strong, and the equitable considerations of fair hearing and of penalizing fraud weigh more compellingly" (quoting Los Angeles Airways, Inc. v. Hughes Tool Co., 95 Cal. App. 3d 1, 7, $156 \mathrm{Cal}$. Rptr. 805, 808 (1979)) (emphasis added).

so See, e.g., Compton v. Compton, 101 Idaho 328, 334, 612 P.2d 1175, 1182 (1980) ("extreme degree of fraud" required); Garmisa v. Garmisa, 4 Ill. App. 3d 411, 280 N.E.2d 444 (1972); Land v. Land, 605 P.2d 1248, 1251 (Utah 1980) (decree will be set aside only "with great reluctance and for compelling reasons"). 
relationship doctrine.

\section{Procedural Fairness}

\section{A. The Confidential Relationship}

The confidential relationship concept lies at the heart of the traditional system of "protective" principles in domestic law. It stems from a recognition of the almost unique community of interests in marriage, the degree of mutual trust and confidence between the parties, and the resulting expectation that one spouse will act in the other's best interest. The extraordinary nature of the husband-wife relationship, however, creates equally extraordinary opportunities for abuse of the relationship, and domestic law principles have long sought to protect against that potential for abuse.

For historical reasons, the confidential relationship concept became identified with, and embodied in, the notion that state intervention was necessary to protect wives, presumptively incapable of protecting themselves, from the domination of their husbands. ${ }^{60}$ The fundamental assumptions that underlie the concept, however, are clearly independent of such stereotypical marital roles. Thus the confidential relationship concept, stripped of its sexist implications, has become a critical step in the arguments of those who assert that existing contract doctrine already provides sufficient procedural safeguards. ${ }^{61}$ The older formulation of the concept was undoubtedly demeaning to wives and burdensome for husbands; the latter assertion is questionable for quite different reasons.

In most states spousal duties to deal fairly with each other, including some form of a duty to disclose, arise either as a result of the common law presumption that husbands and wives occupy a confidential relationship ${ }^{62}$, or from a statute embodying that presumption. ${ }^{63}$ In a

${ }^{60}$ See L. WeITzMan, supra note 8, at 344. A somewhat more caustic explanation of the relationship in an antenuptial context is provided by Gamble, supra note 17, at 720: "Having recognized the mental frailty of the infatuated woman, the courts have become her self-proclaimed protector . . . ."

61 Professor Weitzman considers the confidential relationship doctrine to "stand half way between the general contract law standards and traditional family law standards." L. WeItzMan, supra note 8, at 345. For her, this concept demonstrates how the courts have developed a doctrinal tool to police procedural unfairness in agreements between spouses, and thus it should encourage more recognition of interspousal contracts. See id. at 346 . Homer Clark points out that the confidential relationship concept imposes a duty that surpasses that normally required in commercial contracts, but that it appears in other contexts, such as between a director and the corporation, as well. Clark, supra note 18, at 144.

62 See, e.g., Vai v. Bank of Am. Nat'l Trust \& Sav. Ass'n, 56 Cal. 2d 329, 364

[Note 63 appears on page 1415.] 
growing but still relatively small number of states, the existence of a confidential relationship may be regarded as a question of fact, so that the relevant inquiry becomes one of whether or not one party did in fact, and with justification, impose trust and confidence in the other. ${ }^{64}$ Similar but nonetheless significantly different ${ }^{65}$ fiduciary duties are commonly imposed in community property states and are derived from spousal management and control of the assets of the marital community. ${ }^{66}$ The distinction between fiduciary and confidential relationships

P.2d 247, 15 Cal. Rptr. 71 (1961); Daffin v. Daffin, 567 S.W.2d 672, 678 (Mo. App. 1978) (husband and wife relation "entails the highest trust and confidence and justifies their mutual reliance"); Christian v. Christian, 42 N.Y.2d 63, 72, 365 N.E.2d 849, 855, 396 N.Y.S.2d 817, 823 (1977) ("Agreements between spouses . . . involve a fiduciary relationship requiring the utmost of good faith."); Key v. Key, 388 P.2d 505, 510 (Okla. 1964) (confidential relationship requires scrutiny for even the "slightest trace" of unfair dealing) (quoting Brasier v. Brasier, 200 P.2d 427 (Okla. 1948)).

os See statutes cited supra note 37.

64 In the words of the Maryland Court of Appeals, one must show that "he is justified in assuming the other party will not act in a manner inconsistent with his welfare." Bell v. Bell, 38 Md. App. 10, 379 A.2d 419, 421 (1977) (confidential relationship held not to exist where wife negotiated several changes in the settlement agreement). See also Francois v. Francois, 599 F.2d 1286, 1292 (3d Cir. 1979) (confidential relationship found where husband turned over his finances to wife), cert. denied, 444 U.S. 1201 (1980); In re Marriage of Connolly, 23 Cal. 3d 590, 591 P.2d 911, 153 Cal. Rptr. 423 (1979) (en banc); Baker v. Baker, 394 So. 2d 465 (Fla. Dist. Ct. App.), cert. denied, 402 So. 2d 607 (Fla. 1981); Wimmer v. Wimmer, 287 Md. 663, 414 A.2d 1254 (1980); Unser v. Unser, 86 N.M. 648, 526 P.2d 790 (1974); DePaul v. DePaul, 287 Pa. Super. 244, 429 A.2d 1192 (1981).

os See infra text accompanying notes 98-102.

(6) The distinction between the two types of relationships was succinctly described in Vai v. Bank of Am. Nat'l Trust and Sav. Ass'n, 56 Cal. 2d 329, 338, 364 P.2d 1247, 1252, $15 \mathrm{Cal}$. Rptr. 71, 76 (1961) (fiduciary duty required husband to divulge all information, including an offer to purchase property for substantially over its ascertained market value):

The confidential relationship and obligations arising out of it are . . . dependent upon the existence of confidence and trust, but the husband's fiduciary duties in respect to his wife's interest in the community property continue as long as his control of that property continues, notwithstanding the complete absence of confidence and trust and the consequent termination of the confidential relationship. The prerequisite of a confidential relationship is the reposing of trust and confidence by one person in another who is cognizant of this fact. The key factor in the existence of a fiduciary relationship lies in control by a person over the property of another. It is evident that while these two relationships may exist simultaneously, they do not necessarily do so.

The fiduciary duty arose from the fact that, until recently, the husband was deemed to be the sole manager of all community property. W. REPPY \& C. SAMUEL, Community Property in the United States 205 (1982). The demise of that rule in favor of the "equal manager" concept, however, has not resulted in the demise of the manager's duty. Rather, that duty has become sex neutral. See, e.g., Boeseke v. Boeseke, 10 Cal. 3d 844, 519 P.2d 161, 112 Cal. Rptr. 401 (1974); Rivers v. Rivers, 381 So. 2d 573 (La. Ct. App. 1980).

Idaho has taken the position that the "solemn duty of a fiduciary" is imposed on both husbands and wives precisely because of their equal control over community prop- 
in the domestic law context, however, is frequently ignored in common law states, where the two terms may sometimes be used interchangeably. ${ }^{67}$

Although the precise scope and extent of the good faith or confidential relationship duties imposed on spouses vary considerably from state to state, the broad outlines of the responsibilities imposed are relatively clear. In general, courts impose a duty on one in whom trust and confidence have been reposed to act in the best interests of the person reposing such trust. A party to a confidential relationship is under a duty not to use any position of superior knowledge, or influence, ${ }^{68}$ to the detriment of the other ${ }^{69}$ This is often said to include a duty to disclose the extent and nature ${ }^{70}$ of marital or community assets, ${ }^{71}$ and it encompasses a duty not to misrepresent or conceal such assets. ${ }^{72}$ Often

erty. See Compton v. Compton, 101 Idaho 328, 335, 612 P.2d 1175, 1182 (1980); Bodine v. Bodine, 103 Idaho 185, 646 P.2d 427 (1982). North Carolina has also imposed an independent duty of disclosure on a husband by virtue of his position as manager of a corporation whose stock was being transferred. Link v. Link, 278 N.C. 181, 179 S.E.2d 697 (1971).

67 See 13 S. Williston, A Treatise on the Law of Contracts § 1625, at 777-78 (3d ed. 1970); see also G.A.S. v. S.I.S., 407 A.2d 253 (Del. Fam. Ct. 1978); Christian v. Christian, 42 N.Y.2d 63, 365 N.E.2d 849, 396 N.Y.S.2d 817 (1977).

${ }^{68}$ Duress is in fact probably the most frequent product of abuse of a confidential relationship. Although duress often occurs in combination with misrepresentation or concealment of property, it is treated separately infra text accompanying notes 126-34. 69 See Bell v. Bell, 38 Md. 10, 379 A.2d 419 (1977); Butler v. Butler, 464 Pa. 522, 347 A.2d 477 (1975).

70 Apparently, however, there is no duty to disclose the value of marital property. This is generally true whether the disclosure duty derives from a confidential relationship or from the community property fiduciary relationship. As one court noted, "each spouse is free to adopt a position favorable to himself or herself regarding the property's valuation, its inclusion in the community, or other such issues." Compton v. Compton, 101 Idaho 328, 336, 612 P.2d 1175, 1183 (1980). See also In re Marriage of Connolly, 23 Cal. 3d 590, 597, 591 P.2d 911, 915, 153 Cal. Rptr. 423, 427 (1979) (en banc) (failure of husband to reveal that stock was about to go public was not a breach of fiduciary duty where even a "cursory examination" by wife's attorney would have revealed the pending sale); Boeseke v. Boeseke, 10 Cal. 3d 844, 519 P.2d 161, 112 Cal. Rptr. 401 (1974) (no duty to value property); Garmisa v. Garmisa, 4 Ill. App. 3d 411, 280 N.E.2d 444 (1972) (failure of husband to reveal negotiations for sale of stock insufficient to warrant setting aside decree).

These cases, of course, should be distinguished from those involving actual misrepresentations of the value of property. In the latter instance, a fraud has been committed. See, e.g., Adams v. Adams, 376 So. 2d 1204 (Fla. Dist. Ct. App. 1979) (decree vacated where husband assigned value of $\$ 290,000$ to Kentucky Fried Chicken holdings worth well over eight million dollars); Bellow v. Bellow, 40 Ill. App. 3d 442, 352 N.E.2d 427 (1976) (husband's actual income five times greater than he represented); Hager v. Hager, 6 Mass. App. Ct. 906, 378 N.E.2d 459 (1978) (husband estimated as "worthless" shares of stock in fact worth over one million dollars); Alexander v. Sagehorn, 600 S.W.2d 198 (Mo. Ct. App. 1980) (gross undervaluation of farm acreage sufficient fraud to warrant setting aside property division portion of decree).

71 See cases cited supra note 70.

72 See infra text accompanying notes 114-15. 
evidence that a confidential relationship existed will shift the burden of proving the substantive or procedural fairness of the transaction to the party seeking to uphold it. ${ }^{73}$

At a minimum, agreements that are the product of a confidential relationship will be scrutinized carefully and may often be set aside on grounds that would not suffice with other types of contracts. ${ }^{74}$ Breach of this general duty appears in fact to be the real basis for many decisions in which fraud, duress, or undue influence is found when the sufficiency of the evidence of such misconduct is doubtful at best. ${ }^{75}$

Despite such relatively well-defined duties, however, the confidential relationship concept is often inadequate to protect against the opportunities for unfair bargaining inherent in the husband-wife relationship. This is true mainly because the duty to deal fairly derives in many instances not from the existence of the husband-wife relationship per se but rather from proof that the parties maintained a relationship of trust and confidence until the execution of a settlement agreement. ${ }^{76}$ And to the degree that an affirmative duty to bargain in good faith, or to disclose marital property, ${ }^{77}$ is contingent on the continued existence of a confidential relationship, such duties may be ephemeral indeed, given the general rules governing the termination of confidential relationships between spouses.

Confidential relationships are generally said to terminate when parties withdraw their trust and confidence from each other and begin

${ }^{23}$ See Francois v. Francois, 599 F.2d 1286 (3d Cir. 1979), cert. denied, 444 U.S. 1201 (1980); In re Marriage of Cohn, 18 Wash. App. 502, 569 P.2d 79 (1977); Marshall v. Marshall, 273 S.E.2d 360 (W. Va. 1981). Washington and West Virginia have statutes that mandate this result. See WASH. REv. CoDE ANN. § 26.16 .210 (1961) (burden of proof on "party asserting the good faith"); W. VA. CoDE $§$ 48-3-7 (1980) (party in whose favor transaction made has burden of showing transfer was "in all respects lawful and valid").

${ }^{74}$ See Christian v. Christian, 42 N.Y.2d 63, 71-72, 365 N.E.2d 849, 855, 396 N.Y.S.2d 817, 824 (1977) (citations omitted): "Equity is so zealous in this respect that a separation agreement may be set aside on grounds that would be insufficient to vitiate an ordinary contract ...."; 1 A. LINDEY, supra note 2, §3, at 3-19 ("Separation agreements may be vitiated upon grounds that would be insufficient to set aside ordinary contracts." (footnote omitted)); 2 id. \$37, at 37-6 ("Transactions between spouses are not presumptively fraudulent; they are merely scrutinized more closely than where no confidential relations exist." (footnote omitted)).

${ }^{70}$ See infra text accompanying notes 120-22.

${ }^{36}$ This should be compared, for instance, with the attorney-client relationship, where the confidential relationship exists regardless of any actual trust or confidence between the parties, and often continues after the termination of the relationship. See Model Code of Professional Responsibility Canon 4 (1981).

77 This is an especially critical problem with the duty to disclose, since failure to disclose will not constitute fraud sufficient to set aside a decree, or sometimes even an unincorporated agreement, in the absence of a continuing duty to disclose. See infra text accompanying notes $117-18$. 
to deal at arm's length. ${ }^{78}$ In family law, however, the termination of the relationship has traditionally not been regarded as a question of fact. Rather it has often been identified with the occurrence of certain discrete events, including filing an action for divorce, ${ }^{79}$ securing representation by an attorney, ${ }^{\mathbf{8 0}}$ or in some instances merely separating or announcing an intention to separate. ${ }^{\mathbf{8 1}}$ In particular, it appears that the dependent party's retaining independent counsel is a critical event that will automatically transform, under the law of many states, the relationship from confidential to arm's length. ${ }^{\mathbf{8 2}}$

When these termination rules are combined with the fact that good faith and disclosure duties are usually derived from, and are thus coterminous with, the continued existence of the confidential relationship, the result is harsh indeed. A spouse, for example, who seeks advice from a lawyer may often suffer a uniquely heavy penalty-an abrupt and automatic withdrawal of most of the protective principles in the traditional system.

Derivation of good faith duties from a relationship so easily terminated is unfortunate for additional reasons as well. First, neither separation of the spouses nor the filing of a matrimonial action obviates the need for a continuing imposition of such duties. To suggest, as one court did, that a husband's announcement of his intention to procure a

782 A. Lindey, supra note $2, \S 37$, at 37-10; see also In re Marriage of Connolly, 23 Cal. 3d 590, 591 P.2d 911, 153 Cal. Rptr. 423 (1979) (en banc); Brennan v. Brennan, 124 Cal. App. 3d 598, 177 Cal. Rptr. 520 (1981). At this point the distinction between fiduciary duties, derived from joint control of property, and confidential relationship duties becomes critical. See supra note 61 .

${ }_{70}$ See, e.g., In re Marriage of Connolly, 23 Cal. 3d 509, 591 P.2d 911, 153 Cal. Rptr. 423 (1979) (en banc) (once wife filed for divorce, relationship became adversarial); Blair v. Blair, 140 Mont. 278, 370 P.2d 873 (1962); Harder v. Harder, 49 Or. App. 675, 619 P.2d 1367 (1980) (no fiduciary relationship between parties to divorce proceedings).

${ }^{\text {80 }}$ See, e.g., Zakoor v. Zakoor, 240 So. $2 d 193$ (Fla. Dist. Ct. App. 1970) (no disclosure duty for husband once wife is represented by attorney); Murphy v. Murphy, 34 N.C. App. 677, 680-81 239 S.E.2d 597, 599-600 (1977) ("where the wife employs an attorney and through him, deals with her husband as an adversary, the confidential relationship between husband and wife no longer exists and there is no presumption of unfairness"), rev'd on other grounds, 295 N.C. 390, 245 S.E.2d 693 (1978).

${ }^{81}$ Le Bert-Francis v. Le Bert-Francis, 194 A.2d 662 (D.C. 1963) (parties separated and negotiated a separation agreement); Applebaum v. Applebaum, 93 Nev. 382 , 566 P.2d 85 (1977).

${ }^{82}$ See, e.g., Kerslake v. Kerslake, 609 P.2d 559 (Alaska 1980); Sullivant v. Sullivant, 293 Ark. 953, 396 S.W.2d 279 (1965); Zakoor v. Zakoor, 240 So.2d 193 (Fla. Dist. Ct. App. 1970); In re Marriage of Lawrence, 642 P.2d 1043 (Mont. 1982); Unser v. Unser, 86 N.M. 648, 526 P.2d 790 (1974); Gorman v. Gorman, 87 A.D.2d 674, 448 N.Y.S.2d 823 (1982); Harder v. Harder, 49 Or. App. 675, 619 P.2d 1367 (1980); McGannon v. McGannon, 359 A.2d 431 (Pa. Super. 1976); see also supra note 78 and accompanying text. 
divorce put his wife "on notice that their interests were adversarial"8s blatantly ignores the psychological dependencies of the parties that led to the creation of the confidential relationship concept in the first instance.

Furthermore, although it is clear that securing counsel may in fact symbolize the end of a confidential relationship, or even remove the need for the protection derived therefrom, it seems equally clear that obtaining independent representation often correlates poorly with the actual termination of the trust relationship. ${ }^{84}$ So long as the negotiation process remains relatively "friendly," one party may easily keep the other in ignorance of marital assets without resorting to concealment or outright misrepresentation. ${ }^{85}$ The arguments that have persuaded some courts to treat the existence of a confidential relationship as a question of fact are even more compelling in the context of determining its termination..$^{88}$ At a minimum, representation by counsel should be accorded the same treatment as nonrepresentation-evidence, considered along with other relevant circumstances, that a confidential relationship did or did not exist. ${ }^{87}$ That the single act of obtaining counsel can effec-

8s Applebaum v. Applebaum, 93 Nev. 382, 385, 566 P.2d 85, 87 (1977).

st See infra note 91 .

${ }^{85}$ In Bellow v. Bellow, 40 Ill. App. 3d 442, 352 N.E.2d 427 (1976), for instance, a settlement agreement was negotiated with both parties represented by attorneys. It failed even to refer to a $\$ 10,000$ account (money the husband had withdrawn and kept), recited that a jointly owned apartment was the separate property of the husband (at trial the husband testified that "'well, I paid for it and assumed it was mine." "Id. at 430, 40 Ill. App. 3d at 444), and estimated husband's income at $\$ 30,000$ when it was in fact $\$ 150,000$. The court reluctantly set aside the settlement decree in view of wife's representation by able counsel.

In Martin v. Martin, 74 A.D.2d 419, 427 N.Y.S.2d 1002 (1980), a separation agreement was upheld despite claims of nondisclosure and despite New York's strong adherence to confidential relationship principles on the grounds that "a husband's failure or refusal to disclose his financial circumstances when the agreement is executed is not sufficient to void an agreement fair on its face . . ." Id. at 424, 427 N.Y.S.2d at 1005. See also Gorman v. Gorman, 87 A.D.2d 674, 448 N.Y.S.2d 823 (1982). With the enactment of equitable distribution in New York, however, the continued validity of that rule is questionable. See Oberstein v. Oberstein, 93 A.D.2d 374, 462 N.Y.S.2d 447 (1983); Ezratty v. Ezratty, 114 Misc. 2d 22, 450 N.Y.S.2d 694 (1982).

${ }_{\text {86 }}$ See, e.g., DePaul v. DePaul, 287 Pa. Super. 244, 429 A.2d 1192 (1981) (importance of factual determination of a confidential relationship whenever one person has placed confidence in another) (quoting Moreland v. Metrovich, $249 \mathrm{~Pa}$. Super. 88, 95, 375 A.2d 772 (1977)).

${ }_{87}$ See, e.g., Whitney v. Seattle-First Nat'l Bank, 90 Wash. 2d 105, 597 P.2d 937 (1978); Marshall v. Marshall, 273 S.E. 2d 360, 363 (W. Va. 1981). That one party is not represented by counsel is highly probative of the continuation of a confidential relationship. The remarks of a Florida court are typical: that wife was not represented by counsel "only underscores the necessity for full compliance with the fiduciary responsibilities inherent in the marital relationship." Baker v. Baker, 394 So. 2d 465, 468 (Fla. Dist. Ct. App.), cert. denied, 402 So. 2d 607 (Fla. 1981). See also In re Marriage of Kesler, 59 Ohio Misc. 33, 392 N.E.2d 905 (1978). Courts, however, have consist- 
tively insulate one spouse from the dominance, influence, or superior knowledge of the other is not borne out by the cases or by common experience.

It is also important to note that the traditional triggering events for termination of a confidential relationship may be within the exclusive control of only one of the spouses. ${ }^{88}$ Thus a husband or wife may file an action for divorce and simultaneously terminate both the confidential relationship and the duties derived from it, precisely at the time when the other spouse may be most vulnerable, upset, and in need of the protection afforded by good faith and disclosure duties. ${ }^{89}$

Finally and most importantly, the dichotomization of the husbandwife relationship as either arm's length or confidential simply does not reflect the realities of such relationships. ${ }^{90}$ Trust, confidence, reliance, psychological dependencies, and patterns of interaction built up over a period of years rarely disappear when, for instance, one party moves out of the house and the other telephones a lawyer. Indeed, that spouses seek a nonlitigious solution to the problems of dissolution indicates that they are not "strangers" for whom arm's length negotiating principles are appropriate.

Common sense and experience bear this out. So do the large number of patently unfair settlement agreements signed by a spouse who is represented by an attorney ${ }^{91}$ and the surprisingly large number of such

ently refused to set aside agreements solely on the grounds of lack of independent representation. See Brennan v. Brennan, 124 Cal. App. 3d 598, 177 Cal. Rptr. 520 (1981); Lowery v. Lowery, 195 Colo. 86, 575 P. 2d 430 (1978); Bubenik v. Bubenik, 392 So. 2d 943 (Fla. App. 1980); Levine v. Levine, 56 N.Y.2d 42, 436 N.E.2d 476, 451 N.Y.S.2d 26 (1982); Whitney, 90 Wash. 2d 105, 579 P.2d 937 (1978). Where virtually all forms of misconduct combine, on the other hand, courts will go to great lengths to void the resulting agreements. For particularly egregious circumstances, see Demaggio v. Demaggio, 327 So. 2d 848 (Fla. App. 1975); Eckstein v. Eckstein, 38 Md. App. 506, 379 A.2d 757 (1978); Daffin v. Daffin, 567 S.W.2d 672 (Mo. App. 1978).

${ }_{88}$ There are suprisingly few cases referring to this problem, but see In re Marriage of Stenquist, 21 Cal. 3d 799, 582 P.2d 96, 148 Gal. Rptr. 9 (1978); In re Marriage of Lucero, $118 \mathrm{Cal}$. App. 3d 836, 173 Gal. Rptr. 680 (1981).

89 With little or no analysis, some courts have reached the opposite conclusion. See, e.g., Harder v. Harder, 49 Or. App. 582, 585, 619 P.2d 1367, 1370 (1980) ("The trust, confidence, faith and reliance of the parties in one another is very high before the altar but correspondingly low before the bench.").

${ }^{20}$ In Stauffer v. Stauffer, 465 Pa. 558, 570, 351 A.2d 236, 242 (1976), the court properly observed that "[h]uman relationships are frequently too complex to be classified simply as either 'confidential' or 'arm's-length'; a relationship can have elements of confidentiality without being strictly a "confidential relationship." "

o1 See, e.g., Boeseke v. Boeseke, 10 Cal. 3d 884, 519 P.2d 161, 112 Cal. Rptr. 401 (1974); Adams v. Adams, 376 So. 2d 1024 (Fla. Dist. Ct. App. 1979); Zeeb v. Zeeb, 76 Ill. App. 3d 894, 395 N.E.2d 660 (1979); In re Marriage of Lawrence, 642 P.2d 1043 (Mont. 1982); Diers v. Diers, 185 Neb. 552, 177 N.W.2d 503 (1970); Unser v. Unser, 86 N.M. 648, 526 P.2d 790 (1974); In re Marriage of Hadley, 88 Wash. 2d 649, 565 P.2d 790 (1977). In all of these cases parties were held to the agreement. Interestingly 
agreements executed by a party who is hoping, and has often been led to expect, that a reconciliation will ensue if the agreement is signed. ${ }^{\mathbf{2}}$ Although a later portion of this Article will treat the issues created by agreements procured through such promises of reconciliation, ${ }^{83}$ the frequency with which the problem arises indicates that spouses do remain susceptible to abuses of trust and confidence long after separation and despite representation by counsel. As one court has noted with considerable understatement, the traditional approach to termination of the confidential relationship relies "heavily on formalisms and too little on basic equitable principles."

Good faith duties, including the duty to disclose the nature and extent of marital assets, should be imposed without regard to any technical terminating events, for at least as long as one party occupies in fact a position of superior knowledge or influence. ${ }^{98}$ More realistically, however, no real solution to the problems that result from the traditional confidential relationship rules is possible so long as the rationale for the imposition of special duties, and particularly the critically important duty to disclose, arises from the continued existence of that relationship.

Fundamentally, the confidential relationship concept is inadequate as a vehicle for imposition of meaningful disclosure duties with regard to separation agreements ${ }^{96}$ because it presumes that such duties are

enough, however, in Bradshaw v. Bradshaw, 578 P.2d 762 (Okla. Ct. App. 1977), the fact that a wife signed an agreement contrary to the advice of an attorney was a factor supporting the court's conclusion that she was the victim of undue influence.

${ }^{22}$ See cases cited infra notes 148 \& 150 . For illustrative purposes the case of Murphy v. Murphy, 34 N.C. App. 677, 239 S.E.2d 597 (1977), is instructive. The wife made what the court of appeals characterized as a "bad bargain," based on her husband's assertions that "the agreement was temporary, that he needed the agreement to effect a loan, that he loved her and would resolve any difficulties and resume marital relations." Id. at 681,239 S.E.2d at 600 . The court upheld the agreement against a claim of undue influence largely on the grounds that, because wife had been represented by counsel, any confidential relationship had terminated. The Supreme Court reversed, ruling that acts of sexual intercourse between parties after execution had voided the agreement; but it affirmed on the undue influence issue. Murphy v. Murphy, 295 N.C. 390,245 S.E.2d 693 (1978).

os See infra text accompanying notes 148-59.

or Simonds v. Simonds, 45 N.Y.2d 233, 243, 408 N.Y.S.2d 359, 365 (1978).

85 See supra note 64 for those states that treat the confidential relationship as a question of fact. See also Ronnkvist v. Ronnkvist, 331 N.W.2d 764 (Minn. 1983), where the court found that failure to disclose property acquired after separation and oral stipulations but prior to the divorce decree constituted fraud sufficient to set aside the judgment; Verschell v. Pike, 85 A.D.2d 690, 445 N.Y.S.2d 489 (1981); Link v. Link, 278 N.C. 181, 179 S.E.2d 697 (1971), discussed infra text accompanying notes 180-84.

os Arguably, similar inadequacies do not occur with antenuptial agreements, where the confidential relationship is usually presumed to exist. Thus meaningful disclosure duties can be imposed. See supra note 18. But see Gamble, supra note 17, at 
necessary only to extend protection to a party who, either presumptively or actually, is susceptible to overreaching or undue influence. It thus ignores the broader interest of the state in the protection of both spouses during and after divorce, ${ }^{97}$ and in the creation of essentially fair bargaining procedures. More importantly, it overlooks the fact that the husband-wife relationship itself, whether confidential or not, should be the basis for imposition of special duties.

The fiduciary duties imposed by most community property states, on the other hand, offer a more satisfactory basis for imposition of meaningful disclosure duties independent of, although not necessarily in lieu of, ${ }^{98}$ those derived from the confidential relationship. These duties, based on joint or managerial control over community property assets, are usually broad: they include, at a minimum, "a disclosure by both parties of all information within their knowledge regarding the existence of community property and of pertinent facts necessary to arrive at a reasonable valuation of the property."

Indeed, fiduciary disclosure duties are often, at least at a practical level, almost as comprehensive as any duties that might be derived solely from the existence of the husband-wife relationship. They are, for instance, unaffected by any of the events that trigger termination of the confidential relationship, ${ }^{100}$ and may well continue "until the mo-

720-23. Professor Gamble finds that some courts do not presume a confidential relationship to exist but make a factual determination concerning it. He considers this factual approach as flawed as that which presumes the existence of a confidential relationship upon the occurrence of specific events, such as engagement, id. at 723: "[C]ourts vary in determining what facts are sufficient to negate any confidential relationship between prospective spouses," $i d$. at 722 . Professor Gamble suggests that courts should reconsider "whether the confidential relationship doctrine actually serves any useful function today," and implies that they should abandon it. Id. at 723.

It is also significant that the doctrine arose at a time when, in common law states, there existed no real concept of marital property. Entitlements upon divorce existed, if at all, only within a system of alimony based upon fault. See H. CLARK, supra note 3, $\S 14.5$, at $445-46$. As a result, equal knowledge of the assets by the parties was somewhat irrelevant.

o7 See H. ClARK, supra note $3, \S 16.2$, at 525 (duty of disclosure "should not be rested on a finding of a confidential relationship which often does not in fact exist, but upon the public interest in having the wife and children provided for in a manner bearing some relation to the husband's true means" (footnote omitted)).

${ }^{88}$ See supra text accompanying note 66; see also Compton v. Compton, 101 Idaho $328,335,612$ P.2d 1175, 1182 (1980).

89 Compton v. Compton, 101 Idaho 328, 336, 612 P.2d 1175, 1183 (1980) (fiduciary duty satisfied where husband disclosed contract for sale of stock and possible increased value of family property). See also Jorgensen v. Jorgensen, 32 Cal. 2d 13, 193 P.2d 728 (1948); Pitre v. Pitre, 247 La. 594, 599, 172 So. 2d 693, 695 (1965) (husband owes to wife "the duty of full disclosure of the community property and its value, and must not conceal or misrepresent any material fact upon which she has a right to rely and upon which she might rely").

${ }^{100}$ See Boeseke v. Boeseke, 10 Cal. 3d 844, 849, 519 P.2d 161, 164, 112 Cal. 
ment of the marriage's termination."101 The partnership analogy has long formed the doctrinal linchpin for imposition of such strict fiduciary duties. The Supreme Court of California has argued persuasively that fiduciary duties imposed on spouses should equal those of business partners.

Manifestly, the fiduciary duties and rules governing their performance by a husband should be no fewer or less rigorous than those imposed upon business partners. To hold . . . that if a wife employs able counsel upon whom she relies in negotiating a property settlement agreement ... her husband is thereby released from any fiduciary duties in respect to her interest in the community property, would put a wife in a far less protected position than a partner whose partnership is being dissolved. ${ }^{102}$

Moreover, given the widespread adoption of equitable distribution statutes, and the partnership analogy principle embodied in such statutes, ${ }^{103}$ it appears that the fiduciary duty concept could be adapted to equitable distribution systems as well as community property systems. ${ }^{104}$ Certainly the suggestion merits serious consideration.

Rptr. 401, 404 (1974); Ronnkvist v. Ronnkvist, 331 N.W.2d 764, 766 (Minn. 1983); 1 A. LINDEY, supra note $2, \S 3$, at 3-20.

101 Compton v. Compton, 101 Idaho 328, 335, 619 P.2d 1175, 1182 (1980). The relationship, however, does not include a duty to value property. See supra note 70 . 102 Vai v. Bank of Am. Nat'l Trust and Sav. Ass'n, 56 Cal. 2d 329, 339, 364 P.2d 247, 253, 15 Cal. Rptr. 71, 77 (1961). See also Boeseke v. Boeseke, 10 Cal. 3d 884, 519 P.2d 161, 112 Cal. Rptr. 401 (1974).

10s With the recent additions of Virginia and West Virginia to the list of states that have adopted some form of equitable distribution, Mississippi is apparently the sole remaining common law property state. See Sharp, Equitable Distribution of Property in North Carolina: A Preliminary Analysis, 62 N.G.L. REv. 247 (1983); see also LaRue v. LaRue, 304 S.E.2d 312 (W. Va. 1983) (a judicial adoption of equitable distribution); VA. CoDE $\S 20-107.3$ (1983). The good faith and disclosure duties on business partners do continue past formal dissolution and throughout the "winding up" or liquidation phase. See, e.g., Lavin v. Ehrlich, 80 Misc. 2d 247, 363 N.Y.S.2d 50 (1974); Johnson v. Peckham, 132 Tex. 148, 120 S.W.2d 786 (1939); Karle v. Seder, 35 Wash. 2d 680, 214 P.2d 684 (1950).

${ }^{104}$ Many states define marital property more narrowly than community property, so that a disclosure duty derived from the nature of the property would not sweep so broadly in such states. See Sharp, supra note 103, at 248-49. Since spouses have less reason to conceal or misrepresent the nature of separate property, however, imposition of such a duty would still constitute an effective means of ensuring that the spouses have equal knowledge of most property subject to division, and thus subject to negotiation. In fact, however, spouses should be required to disclose all information relevant to an equitable distribution. See Ronnkvist v. Ronnkvist, 331 N.W.2d 764 (Minn. 1983); infra text accompanying notes 224-25. Since the separate assets of each party are factors which most states consider in determining what constitutes an "equitable" distribution of marital property, disclosure of separate property should also be required. Note, Property Division and Alimony Awards: A Survey of Statutory Limitations on Judicial 
The traditional confidential relationship concept clearly does not provide an adequate basis for what is probably the single most critical aspect of procedural fairness, that each party is guaranteed the means to obtain equal knowledge of the nature and extent of marital property. Its termination rules make a mockery of meaningful disclosure duties. The morals of the marketplace, as Justice Cardozo observed in a joint venture case, are inappropriate for any enterprise that requires the "duty of the finest loyalty." solution of marriage.

\section{B. Fraud, Misrepresentation, and Concealment}

Not surprisingly, numerous forms of unfair bargaining tactics may so contaminate the bargaining process as to void, in whole or in part, the resulting settlement agreement. Indeed, parties obtaining a divorce rarely restrict themselves to one form of bargaining misconduct. ${ }^{106}$ The most commonly alleged ground for challenging the validity of an agreement, and, as noted previously, virtually the only ground for setting aside a decree based on an agreement, is that the contract was procured by fraud. ${ }^{107}$ For a variety of reasons, however, application of fraud principles in this area has proved less than satisfactory as a means of ensuring fairness in the bargaining process.

Fraud is, of course, the great catch-all for irregularities in the bargaining process; and in domestic law, as elsewhere, only human imagination limits the variety of fraudulent practices encountered. Thus, denying a spouse access to an attorney will constitute fraud, ${ }^{108}$ as will procuring a sham attorney for a spouse, ${ }^{109}$ misrepresenting the nature of the agreement signed or the legal action taken, ${ }^{110}$ or, more rarely,

Discretion, 50 FordHAM L. REv. 415, 448 (1981).

${ }^{108}$ Meinhard v. Salmon, 249 N.Y. 458, 463-64, 164 N.E. 545, 546 (1928).

${ }_{106}$ In some instances, one spouse has combined virtually all forms of unfair bargaining conduct. See, e.g., Demaggio v. Demaggio, 317 So. 2d 848 (Fla. Dist. Ct. App. 1975); Eckstein v. Eckstein, 38 Md. App. 506, 379 A.2d 757 (1978); Daffin v. Daffin, 567 S.W.2d 672 (Mo. Ct. App. 1978); Eubanks v. Eubanks, 273 N.G. 189, 159 S.E.2d 562 (1968).

${ }^{107}$ See supra text accompanying notes 48-59. This may include undue influence or duress, discussed infra text accompanying notes 126-89.

${ }^{108}$ See, e.g., cases cited supra note 106.

109 See, e.g., Beck v. Beck, 83 Ill. App. 3d 976, 404 N.E.2d 972 (1980); Beattie v. Beattie, 53 Ill. App. 3d 501, 368 N.E.2d 178 (1977); Daffin v. Daffin, 567 S.W.2d 672 (Mo. 1978); McCarty v. McCarty, 300 S.W.2d 394 (Mo. 1957); Christian v. Christian, 42 N.Y.2d 63, 365 N.E.2d 849, 396 N.Y.S.2d 817 (1977).

110 See, e.g., Crisco v. Crisco, 294 Ala. 168, 313 So. 2d 529 (1975); Moss v. Jacober-Moss, 334 So. 2d 89, 91 (Fla. Dist. Ct. App. 1976); Leach v. Leach, 26 Ill. App. 3d 241, 325 N.E.2d 19 (1975). 
misrepresenting an intention to reconcile. ${ }^{111}$ By far the most frequently encountered allegation of fraud, however, is that one spouse has misrepresented, concealed, or failed to disclose the nature or extent of marital or community property. ${ }^{112}$

Equal or at least roughly equal knowledge by the spouses of the nature and extent of marital assets is a prerequisite to fairness in the bargaining process. That only one spouse possessed such knowledge at the time an agreement was signed, however, may not be fatal to enforcement of the contract, particularly if a decree has already been entered, or if the parties were not involved in a confidential relationship at the time the agreement was executed. Thus determining whether bargaining misconduct that resulted in disparity of knowledge will constitute technical fraud is often not an easy matter. ${ }^{113}$ Actual misrepresentation of assets will constitute fraud sufficient to set aside a decree, ${ }^{114}$ as will concealment of assets in most instances. ${ }^{115}$ Beyond such

311 See infra text accompanying note 156.

112 See, e.g., Modnick v. Modnick, 9 FAM. L. REP. (BNA) 2511 (Cal. May 26, 1983) (husband's failure to disclose community property constitutes extrinsic fraud); $c f$. H. CLARK, supra note $3, \S 16.15$, at 567-71 (discussion of misrepresentation and other types of fraud in separation agreements). The misrepresentation complaint arises with such frequency precisely because parties have sought to avoid the no holds barred consequences of litigation. More often than not, they have relied upon each other's financial affidavits or mere statements of marital assets. Discovery will not normally have occurred during the negotiation process.

118 Technically, of course, fraud is defined as in any other context. There must be misrepresentation of material fact, which is false and known to be false by the party making it, made with the intention that it be relied upon by the other party, and justifiably relied upon by that party to his detriment. See, e.g., Abbate v. Abbate, 82 A.D.2d 368, 441 N.Y.S.2d 506 (1981) (deliberate misrepresentation of husband's income, which, in turn, affected the level of alimony, held to constitute fraud); 2 A. LinDEY, supra note $2, \S 37$, at 37-10 \& n.20.

114 See, e.g., Brennan v. Brennan, 177 Cal. Rptr. 520, 124 Cal. App. 3d 598 (1981) (husband represented that business, worth $\$ 250,000$, was bankrupt); Baker v. Baker, 394 So. 2d 465 (Fla. Dist. Ct. App.), cert. denied, 402 So. 2d 607 (Fla. 1981) (extreme misrepresentation of assets and income); Bellow v. Bellow, 40 Ill. App. 3d 442, 352 N.E.2d 427 (1976); Hager v. Hager, 6 Mass. App. 903, 378 N.E.2d 459 (1978).

${ }_{116}$ See, e.g., Bates v. Bates, 1 Ariz. App. 165, 168, 400 P.2d 593, 596 (1965) ("Extrinsic fraud may also consist of deception practiced by the successful party in purposely keeping his opponent in ignorance." (citation omitted)); Dendrinos v. Dendrinos, 58 Ill. App. 3d 639, 642, 374 N.E.2d 1016, 1018 (1978) ("Fraud may consist in the concealment of what is true as in the assertion of what is false."); Daffin v. Daffin, 567 S.W.2d 673, 677 (Mo. App. 1978) ("Concealment of a material fact . . . which a party has the duty to disclose, constitutes fraud as actual as by an affirmative misrepresentation." ); Abbate v. Abbate, 82 A.D.2d 368, 377, 441 N.Y.S.2d 506, 514 (1979) ("Concealment with intent to defraud of facts which one is duty-bound in honesty to disclose is of the same legal effect and significance as affirmative misrepresentations of fact." ") (quoting Nasaba Corp. v. Harfred Realty Corp., 287 N.Y. 290, 295, 39 N.E.2d 243, 245 (1942)). But see Harder v. Harder, 49 Or. App. 582, 619 P.2d 1367 (1980) (husband's failure to include his interest in a family business as part 
classic examples of fraud, however, the situation is considerably more complex, and courts have sometimes reached notably inconsistent and confusing results. ${ }^{116}$

Where the issue is failure to disclose, a finding of fraud will depend largely upon whether or not a state treats the confidential relationship as a question of fact or recognizes a duty to disclose independent of that relationship. In those states where the duty to disclose remains contingent upon the continued existence of the confidential relationship, failure to disclose will often constitute no breach of duty for the simple reason that no duty existed. ${ }^{117}$ Where there is an independent, or continuing, duty to disclose, on the other hand, breach of that duty will normally be characterized as fraud. ${ }^{118}$ In many instances, however, even within a single state, treatment of the confidential relationship duties cannot account for the disparity in resolution of fraud cases. ${ }^{110}$

Difficulty in reconciling these decisions is undoubtedly due in part to the fact that courts are repeatedly confronted with the difficult task

of marital assets held to be a "mistake"). In some states, moreover, even the most glaring of misrepresentations as to property or its value may be insufficient to set aside a decree. See, e.g., McRae v. Turner, 626 S.W.2d 351 (Tex. Civ. App. 1981); Rylee v. McMorrough, 616 S.W.2d 649 (Tex. Civ. App. 1981); Chapman v. Chapman, 591 S.W.2d 574 (Tex. Civ. App. 1979) (wife had enough information so that she should have been on guard and should not have believed misrepresentation). But see Dudley v. Lawler, 468 S.W.2d 160 (Tex. Civ. App. 1971).

116 See cases cited infra notes 121-22.

117 See, e.g., Garmisa v. Garmisa, 4 Ill. App. 3d 411, 280 N.E.2d 444 (1972); Chapman v. Chapman, 591 S.W.2d 574 (Tex. Civ. App. 1979). Some courts reach this result by resorting to the rationale that reliance is no longer justifiable. Applebaum v. Applebaum, 93 Nev. 382, 384-85, 566 P.2d 85, 87 (1977) ("Once Stephen announced his intention to seek a divorce, Geraldine was on notice that their interests were adverse."); Connolly v. Connolly, 23 Cal. 3d 590, 591 P.2d 911, 916, 153 Cal. Rptr. 423, 428 (1979) ("From the time that wife filed her petition seeking dissolution of the marriage .. . her relationship with her husband was an adversary one.").

118 See, e.g., Ronnkvist v. Ronnkvist, 331 N.W.2d 764 (Minn. 1983) (decree set aside where husband failed to disclose assets he had purchased after an agreement was signed but prior to the divorce decree); Verschell v. Pike, 85 A.D.2d 690, 445 N.Y.S.2d 489 (1981) (although no actual duress or fraud found, agreement rescinded on grounds that wife had failed to reveal her knowledge of a zoning problem, which would have adversely affected the value of the settlement to which the husband had agreed); see also Vai v. Bank of Am. Nat'l Trust \& Sav. Ass'n, 56 Gal. 2d 329, 364 P.2d 247, 15 Cal. Rptr. 71 (1961); Pilati v. Pilati, 181 Mont. 182, 592 P.2d 1374 (1979).

110 Compare Blalock v. Blalock, 51 Ala. App. 686, 288 So. $2 d 747$ (1974) (apparently holding concealment of assets would not amount to fraud in procurement) with Brice v. Brice, 340 So. 2d 792 (Ala. 1976) (agreement set aside for fraud in procurement where wife did not reveal several thousand dollars in debts which husband had agreed to pay) and Garmisa v. Garmisa, 4 IIl. App. 3d 411, 280 N.E.2d 444 (1972) (husband's misrepresentation of value of stock not fraud) with Roth v. Roth, 45 Ill. $2 \mathrm{~d}$ 19, 256 N.E.2d 838 (1970) (wife's misrepresentation of plans to remarry held fraud on the court); see also Hopper v. Hopper, 183 Mont. 543, 601 P.2d 29 (1979); Miller v. Miller, 183 Mont. 543, 616 P.2d 313 (1980). 
of balancing the need to apply standard res judicata and contract principles with the special equitable considerations that soften the application of such principles in domestic relations cases. More often than not, this results in a greater willingness to stretch the traditional definition of fraud to accommodate less egregious forms of misconduct, even in the absence of a confidential relationship. ${ }^{120}$ Thus decrees may be set aside on the grounds of fraud even though no technical fraud has occurred, ${ }^{121}$ or a failure to disclose may be characterized as extrinsic fraud. ${ }^{122}$ Such cases create confusing precedent. They also do considerable damage to principles of res judicata, and thus lend credence to those critics who, accurately in this instance, point out the subjectivity and lack of reliability in the existing system of standards governing the validity and enforcement of settlement agreements. ${ }^{123}$

Much of the confusion engendered by such an elastic application of fraud principles could probably be eliminated if well-defined disclosure duties, independent of the confidential relationship, were imposed on all spouses. Breaches of those duties by failure to disclosure material facts concerning the extent or value of marital assets could thus be consistently accommodated in the definition of actual fraud. ${ }^{124}$

The more fundamental problem, however, is that many of the agreements giving rise to such inconsistent results simply are not the product of bargaining misconduct that warrants characterization as fraud. This is not to say that such agreements are not unfair, or unfairly procured, or that they merit enforcement as valid contracts. And although it may well be true that a degree of inconsistency and flexibil-

1202 A. LINDEY, supra note $2, \S 37$, at $37-10$ to -11 .

121 See, e.g., Sande v. Sande, 83 Idaho 233, 360 P.2d 998 (1961) (no technical fraud but court granted relief to wife because of manifest overreaching by husband); Bradshaw v. Bradshaw, 578 P.2d 762 (Okla. 1977); Verschell v. Pike, 85 A.D.2d 690, 445 N.Y.S.2d 489 (1981).

${ }_{122}$ See, e.g., Pilati v. Pilati, 181 Mont. 182, 592 P.2d 1372 (1974) (where husband failed to disclose all assets, court found extrinsic fraud and redistributed property in an equitable manner); cases cited supra notes 99-100.

${ }^{123}$ See, e.g., L. WeITZMan, supra note 8, at 354 ("family court judges . . . examine agreements in light of the current situation of the parties, and . . . invoke a more subjective standard for reviewing contracts (i.e. one that permits their own definitions of fairness to intrude)"). It should be noted, however, that such criticism has generally been directed at the process of judicial review prior to entry of a decree.

${ }^{224}$ Standards for disclosure with antenuptial agreements, which are generally higher than those with settlement agreements, would provide an obvious and well-developed guide. See Del Vecchio v. Del Vecchio, 143 So. 2d 17, 20 (Fla. 1962) ("A valid antenuptial agreement contemplates a fair and reasonable provision therein for the wife, or absent such provision, a full and frank disclosure to the wife, before the signing of the agreement, of the husband's worth, or, absent such disclosure, a general and approximate knowledge by her of the prospective husband's property."); cases cited supra note 18. 
ity in fraud cases is inevitable, the real point is that the time to provide relief for unfair agreements procured by bargaining misconduct falling short of actual fraud is before, not after, a decree has been entered. So long as courts fail to undertake meaningful substantive review of agreements prior to entry of a final decree, it seems inevitable that principles of law will be sacrificed to principles of equity, or vice versa. ${ }^{126}$

\section{Undue Influence and Duress}

Dissolution of marriage is, of course, an inherently stressful and usually traumatic event. It is therefore extraordinarily productive of the kinds of psychologically vulnerable states in which parties may easily exercise, or fall victim to, various forms of unfair bargaining tactics. Indeed, it is difficult to think of any other event in an individual's life, short of the death of a loved one, that creates greater susceptibilities to overreaching. ${ }^{126}$ Opportunities for such misconduct are only magnified where settlement agreements are negotiated in haste, where one attorney represents both parties, or where one party is not represented at all-all conditions that occur with remarkable frequency. ${ }^{\mathbf{1 2 7}}$ It is thus

${ }^{228}$ See infra text accompanying notes 195-96.

126 It is illuminating to note in this context the explanation for the Federal Trade Commission's recent regulations concerning disclosures about funeral services:

Arranging for a funeral plainly involves emotional, religious, and other important social considerations. At the same time, a funeral . . . is also an expensive consumer purchase ....

... [I]t is a unique transaction, one whose characteristics reduce the ability of consumers to make careful, informed purchase decisions. Decisions must often be made under the emotional strain of bereavement. In addition, consumers lack familiarity with the financial transaction . . . . Further, consumers are called upon to make several important and potentially costly decisions under tight time constraints.

47 Fed. Reg. 42,260 (1982) (codified at 16 C.F.R. $\$ 453$ (1983)). This is one of the prominent instances in which consumers are protected from themselves, at considerable cost to freedom of contract.

${ }_{127}$ See, e.g., In re Marriage of Carlson, 101 Ill. App. 3d 924, 428 N.E.2d 1005 (1981); Baker v. Baker, 394 So. 2d 465 (Fla. Dist. Ct. App. 1980), cert. denied, 402 So. 2d 607 (Fla. 1981). As noted previously, representation by counsel often dissipates any presumption of a confidential relationship. See supra text accompanying note 82. In this context, moreover, independent representation is deemed to have an additional "insulating effect" against any overreaching by the dominant party. McGuire v. McGuire, 385 So. 2d 151, 152 (Fla. Dist. Ct. App. 1980). Thus a party who was represented by counsel will not easily be able to prove duress or undue influence. See, e.g., Sullivant v. Sullivant, 239 Ark. 953, 396 S.W.2d 279 (1965); In re Marriage of Lawrence, 642 P.2d 1043 (Mont. 1982); Gorman v. Gorman, 87 A.D.2d 674, 448 N.Y.S.2d 823 (1982); McGannon v. McGannon, 241 Pa. Super. 45, 359 A.2d 431 (1976). But see Francois v. Francois, 599 F.2d 1286 (3d Cir. 1979) (undue influence found even where husband signed agreement contrary to advice of counsel, although there was some evidence that his counsel was in collusion with his wife); Bradshaw v. Bradshaw, 578 P.2d 762 (Okla. Ct. App. 1977) (wife's signing agreement contrary to advice of 
not surprising to find that undue influence and duress are common allegations by parties seeking to set aside settlement agreements or decrees based on them. ${ }^{128}$ Such defenses bear a close relation to fraud, ${ }^{128}$ and they are also associated with the confidential relationship doctrine. ${ }^{130}$

The general rules governing the interplay of duress, undue influence, and the confidential relationship are similar to those discussed previously. ${ }^{131}$ Proof that such a relationship existed gives rise to a presumption that any advantage procured by the dominant party was the result of abuse of the relationship. Absent proof that the transaction was fair by the party seeking to uphold it, the disadvantaged spouse will often be able to obtain relief, particularly where a decree has not already been entered. ${ }^{132}$ Less commonly, duress and undue influence may also constitute sufficient grounds to warrant setting aside a decree. ${ }^{133}$ Where a confidential relationship did not exist at the time an agreement was signed, on the other hand, duress, and especially. undue influence, may be exceedingly difficult to prove. Given the principles

counsel a factor supporting court's finding of undue influence).

128 Technically, of course, the two defenses are distinguishable. See infra note 130. Courts are often less than technical in their treatment of such misconduct in family law cases, however, and undue influence is frequently subsumed under the broader category of duress.

${ }_{120}$ Undue influence, for example, "has been regarded as a species of duress, as a species of fraud, and as sui generis." Green, Fraud, Undue Influence, and Mental Incompetency, 43 ColuM. L. REv. 176, 179 (1943).

150 Duress may clearly occur between strangers, especially if it takes the form of threats against persons or property. 13 S. Williston, supra note $67, \S 1603$, at 660 63. More commonly, it occurs between parties who occupy some relationship of trust and confidence. And certainly proof of duress is greatly aided if a confidential relationship exists. See Libel v. Libel, 5 Kan. App. 2d 367, 616 P.2d 306 (1980). It has been said, on the other hand, that undue influence "can exist only where one party occupies a position of dominance over the other." Green, supra note 129, at 180-82. See also 13 S. WiLliston, supra note $67, \S 1625$, at $766-70$.

131 See supra text accompanying notes 78-82.

13213 S. WILLISTON, supra note 67, $\$ \S 1625-1627 \mathrm{~B}$, at 776-826; D'Arc v. D'Arc, 164 N.J. Super. 226, 395 A.2d 1270 (1978); see also supra text accompanying notes 45-46.

${ }^{133}$ See, e.g., Link v. Link, 278 N.C. 181, 179 S.E.2d 697 (1971) (conveyance set aside because husband had threatened to take children from wife unless she transferred property). Since victims of duress or undue influence are, unlike victims of misrepresentation or concealment, more apt to be aware of the other party's misconduct prior to entry of a decree, parties seeking relief on such grounds will often be precluded from doing so on the basis of estoppel or ratification. Contracts procured through duress and undue influence are generally voidable, not void. $13 \mathrm{~S}$. Williston, supra note $67, \S$ 1627 , at 810-11. By the time a final decree has been entered, therefore, a party will usually be found to have ratified the agreement, either by acceptance of its benefits or by remaining silent after the duress or undue influence ceased. See Jacobson v. Jacobson, 277 A.2d 280, 283 (D.C. App. 1971); see also Saggese v. Saggese, 15 Md. App. 378, 290 A.2d 794 (1972); Ridings v. Ridings, 55 N.C. App. 630, 286 S.E.2d 614 (1982). 
often governing the termination of the confidential relationship, ${ }^{134}$ moreover, it is once again impossible to avoid a confrontation with inadequacies of that doctrine.

Apart from the fact that confidential relationship rules may undermine the effectiveness of the undue influence and duress defenses, however, the operation of these defenses in the family law area raises serious questions about the adequacy of contract law as a vehicle for the elimination of unfair bargaining tactics between spouses. ${ }^{135}$ In some instances, undue influence and duress principles operate effectively to weed out spurious or doubtful defenses, including especially those cases where one party challenges an agreement on those grounds only after the other has sought enforcement of it. ${ }^{136}$ Courts are justifiably suspicious that such challenges are more likely than not to result from "second thoughts" about "bad bargains."137 In similar fashion, courts have consistently rejected claims of undue influence or duress based solely or largely on a party's allegations that he or she was under great stress when an agreement was signed. ${ }^{138}$ Although the result may differ

1s4 See supra text accompanying notes 76-82.

185 For a discussion of reconciliation promises and custody threats, see infra text accompanying notes 148-89. In an excellent article on problems in traditional contract law and contract defenses, Eisenberg, The Bargain Principle and Its Limits, 95 HaRv. L. REv. 741 (1982), Professor Eisenberg offers an example of a situation that the defense of duress would not cover: a traveler stranded in the desert is forced to make a contract with a passerby, who extracts enormous consideration, to return him to civilization. $I d$. at 755 . He points out that duress would not apply here because, under traditional rules, the promisor, the traveler, would have to have been put in distress by a wrongful act or threat of the promisee, in this case the passerby. Id. Professor Eisenberg then argues that such a contract should not be enforced because the two major supports for the bargain principle ("the common law rule that . . the courts will enforce a bargain according to its terms"; $i d$. at 742), fairness and efficiency, are not satisfied in this case. Id. at 755-56.

${ }^{138}$ In Jacobson v. Jacobson, 277 A.2d 280 (D.C. 1971), the husband performed under the agreement for five years and claimed duress only when his ex-wife attempted to enforce an escalation clause. See also Renois v. Di Franco, 512 S.W.2d 411 (Mo. Ct. App. 1974) (husband made house payments pursuant to agreement for five years, and claimed duress only after wife remarried); Collins v. Johnson, 72 Misc. 2d 1034, 341 N.Y.S.2d 214 (1973) (husband obtained Mexican divorce and remarried, and claimed duress only when ex-wife sought to enforce agreement). Estoppel is of course a readily available defense to such suits. See, e.g., In re Marriage of Wipson, 113 Cal. App. 3d 136, 169 Cal. Rptr. 664 (1980) (wife waited three years to attack decree); Peste v. Peste, 1 Wash. App. 19, 459 P.2d 70 (1970) (wife waited seven years and voluntarily executed a waiver). In Sullivant v. Sullivant, 239 Ark. 953, 396 S.W.2d 279 (1965), a wife waited over 30 years to claim duress.

137 See, e.g., In re Marriage of De Frates, 91 Ill. App. 2d 607, 612-14, 414 N.E.2d 1188, 1192-93 (1980); Horwich v. Horwich, 68 Ill. App. 3d 518, 521, 386 N.E.2d 620, 622 (1979) (court refused to set aside divorce settlement where no fraud, duress, or misrepresentation was present); Saggese v. Saggese, 15 Md. App. 378, 290 A.2d 794 (1972).

${ }^{138}$ See, e.g., In re Marriage of Wipson, 113 Cal. App. 3d 136, 138, 169 Cal. Rptr. 664, 667 (1980) (petitioner's complaint merely evidenced "the trauma and confu- 
where other factors indicating unfair bargaining combine with what a court regards as extraordinary stress, ${ }^{139}$ the basic rule is clear: "internal pressures, personal desires, or a sense of obligation simply do not constitute legal duress." 140

In other situations, however, undue influence and duress sweep too broadly and are inadequate concepts from which to derive remedies for distinctly unfair bargaining practices. This is not particularly surprising; such defenses were designed to operate within a competitive and arm's length market that seeks to maximize freedom of contract. To the degree that the "market" in which such principles operate deviates substantially from that competitive paradigm, however, those principles no longer promote the primary contract values, efficiency and fairness. ${ }^{141}$ And separation and divorce hardly constitute the ideal milieu for operation of such classic bargain principles. The unfortunate result is that concepts of undue influence and duress operate ineffectively as means for elimination of several varieties of exploitation and overreaching between spouses.

One illustration of this problem is presented by the once common situation in which the "price" for obtaining a divorce was an agreement that imposed economic obligations or denied benefits in a manner that egregiously disadvantaged one party. The issue was nicely phrased by one court as "whether a wife's monetary exploitation of her husband's

sion normally present in a dissolution"); Bailey v. Bailey, 300 So. 2d 294, 296 (Fla. Dist. Ct. App. 1974) (insufficient to allege "tremendous emotional strain" since "almost all settlements in domestic relations matters are entered during periods of stress") (citation omitted); Horwich v. Horwich, 68 Ill. App. 3d 518, 386 N.E.2d 620 (1979); Spaulding v. Spaulding, 221 Kan. 574, 561 P.2d 420 (1970); In re Marriage of Lawrence, 642 P.2d 1043 (Mont. 1982); Rado v. Rado, 51 A.D.2d 811, 380 N.Y.S.2d 273 (1976) (abuse of discretion to set aside settlement on grounds that wife was emotionally upset at the time she entered into the agreement).

${ }^{139}$ See Eckstein v. Eckstein, 38 Md. App. 506, 379 A.2d 757 (1978) (duress found where wife had a history of emotional instability, she was not represented by counsel and was without funds, and where husband and his counsel coerced her into signing agreement); Harrigan v. Harrigan, 135 Vt. 249, 373 A.2d 550 (1977). In the relatively rare instances in which a party's stress or other difficulties rendered him or her truly incompetent to contract, agreements will be readily set aside. See, e.g., G.A.S. v. S.I.S., 407 A.2d 253 (Del. Fam. Ct. 1978) (husband was receiving inpatient treatment for paranoid schizophrenia and signed agreement while under the influence of drugs); Galloway v. Galloway, 281 N.W.2d 804 (N.D. 1979).

${ }_{140}$ Wilson v. Wilson, 642 S.W.2d 132, 135 (Mo. App. 1982) (duress not found where husband had made the agreement to encourage wife to pay more attention to their daughter).

141 According to Professor Eisenberg, the bargain principle, the intellectual centerpiece of traditional contract law, is supported by "considerations of both fairness and efficiency." Eisenberg, supra note 135, at 747. To apply this principle-to "enforce a contract according to its terms," $i d$. at 742-in a perfectly competitive market, argues Professor Eisenberg, will promote fairness and economic efficiency. Id. at 745-47. 
midnight fervor for fresh matrimonial ventures can qualify as duress."142 Given the existence until very recently of divorce laws that countenanced, and thus invited, such exploitation by requiring the consent or cooperation of a spouse in order to obtain a divorce, it is not surprising to find courts consistently upholding these types of agreements against claims of duress. ${ }^{143}$ Indeed, in some instances courts endorsed the use of such tactics as justified economic retribution for marital fault. ${ }^{144}$

Fortunately, the opportunities for such judicially sanctioned overreaching have markedly decreased with the advent of widespread nofault divorce and the decreasing role of fault in both alimony awards and property divisions in many states. ${ }^{145}$ Although a party may still pay a relatively high price to avoid litigation or embarrassment, ${ }^{146}$ courts are rarely called upon to limit the freedom of parties to bargain with "chips" created by the substantive divorce laws of a state. ${ }^{147}$

In other situations, however, opportunities for similar kinds of overreaching continue to exist. This is particularly true with agreements induced through promises to reconcile or through threats to sue. Although such tactics result, almost by definition, in the procurement of markedly unfair agreements, undue influence and duress principles have proved largely impotent to provide relief.

One of the more frequent factual situations alleged to constitute

${ }^{142}$ Collins v. Johnson, 72 Misc. 2d 1034, 1036, 341 N.Y.S.2d 214, 217 (1973). See also Clatterbaugh v. Clatterbaugh, 182 Neb. 160, 162, 153 N.W.2d 749, 751 (1967), where the husband was "willing to agree to almost anything to secure a divorce."

14s See, e.g., Martin v. Martin, 74 A.D.2d 419, 425, 427 N.Y.S.2d 1002, 1006 (1980) (agreement upheld where wife deeded her $\$ 50,000$ to $\$ 60,000$ equity in marital home to husband for $\$ 7500$, because she sought to avoid public airing of her adultery, and thus her only option was "to try to obtain a conversion divorce by proposing a separation agreement that her husband would accept"). Technically, such pressures do not constitute duress because petitioner's predicament was not caused by the wrongful acts of the other party. Restatement (SECOND) of ConTRACTs \& 175 (1979).

144 In Bjornstrup v. Cole, 393 P.2d 316, 319 (Wyo. 1964), the court upheld, in vituperative language, an agreement wherein wife received $\$ 2000$ after a 14 -year marriage: the court commented that the wife "got exactly what she wanted . . the man with whom she had committed adultery." See also Harrigan v. Harrigan, 135 Vt. 249, 373 A.2d 550 (1977). The use of such tactics would be likely to raise the issue of unconscionability in other contexts.

${ }^{145}$ See Freed \& Foster, Family Law in the Fifty States: An Overview as of September 1982, 8 FAM. L. REP. (BNA) 4065, 4083-86 (1982). Only Illinois and South Dakota still require some kind of "fault" grounds for divorce.

146 See infra text accompanying notes 160-89.

${ }_{147}$ But see cases cited infra note 176 . The availability of no-fault, even ex parte, divorce also creates a kind of bargaining chip for a party seeking a divorce. But the ability to procure a divorce does not create the imbalance in bargaining strength that the ability to preclude a divorce once did. 
duress is that one party signed an agreement (and often entered a default appearance as well) largely because he or she had been led to believe that a reconciliation would thereby, and only thereby, ensue. ${ }^{148}$ In effect, a spouse pays a "price" not dissimilar to that once often paid to secure a divorce, in order, so he or she believes, to preserve the marriage. ${ }^{149}$ Despite the differences in the motive and tactics underlying "expensive" agreements executed to preserve or to terminate the marriage, judicial response has been the same: the disadvantaged spouse will usually be held to the bargain. ${ }^{180}$

Such results are occasionally due to judicial suspicions of the legitimacy of the allegations. ${ }^{151}$ More fundamentally, such claims fail because they do not fit within the traditional contract defenses. Moreover, at least in family law, the courts have interpreted these defenses with little flexibility. Technically, for example, the promised reconciliation, if viewed as a threat to institute an action for divorce, is not duress since the threatened act-separation or divorce-is not "wrongful."152 Nor does the promise to reconcile constitute fraudulent misrepresentation unless the complaining party can prove, by clear and convincing evidence, that there was a present intent not to perform at the time the promise was made, a burden difficult to meet. ${ }^{153}$ Procuring an agree-

148 It is somewhat remarkable to find that many parties are also induced to sign patently unfair settlement agreements by a promise to remarry. See, e.g., Demaggio v. Demaggio, 317 So. $2 d 848$ (Fla. Dist. Ct. App. 1975) (husband assured wife, hospitalized for alcoholism, that once she was cured he would remarry her); In re Marriage of Hawkins, 106 Ill. App. 3d 68, 435 N.E.2d 786 (1982); Blaising v. Mills, 176 Ind. App. 141, 374 N.E.2d 1166 (1978) (promise of reconciliation held constructive fraud because of duress); Unser v. Unser, 68 N.M. 648, 526 P.2d 790 (1974); McFarland v. Reynolds, 513 S.W.2d 620 (Tex. Civ. App. 1974).

119 Needless to say, the promised reconciliations either do not ensue or last for only brief periods of time.

1so See, e.g., Dunbar v. Dunbar, 102 Ariz. 352, 429 P.2d 949 (1967) (no duress found; settlement agreement enforced); Reynolds v. Reynolds, 415 A.2d 535 (D.C. 1980) (separation agreement enforced); Reininger v. Reininger, 67 Ill. App. 3d 21, 384 N.E.2d 546 (1978); Prochazka v. Prochazka, 198 Neb. 525, 253 N.W.2d 407 (1977); Unser v. Unser, 86 N.M. 648, 526 P.2d 790 (1974); Murphy v. Murphy, 34 N.C. App. 677, 239 S.E.2d 597 (1977) (true reconciliation voided separation agreement), rev'd on other grounds, 295 N.C. 390, 245 S.E.2d 693 (1978); Held v. Held, 8 Or. App. 280, 493 P.2d 1388 (1972) (divorce decree by default upheld). But see cases cited infra note 157, where agreements procured by such means have been set aside on grounds of unfairness or unconscionability.

${ }_{151}$ See, e.g., Prochazka v. Prochazka, 198 Neb. 525, 253 N.W.2d 407 (1977), where the court found the wife's allegations that she signed a property settlement only in order to effect a reconciliation simply unbelievable in view of her earlier pleadings and testimony.

${ }_{162}$ See, e.g., Dunbar v. Dunbar, 102 Ariz. 352, 356, 429 P.2d 949, 953 (1967) ("It is not duress to declare an intention to resort to the courts for the purpose of insisting on what one believes are one's legal rights."); see also Reynolds v. Reynolds, 415 A.2d 535 (D.C. 1980).

15s See, e.g., Unser v. Unser, 89 N.M. 648, 526 P.2d 790 (1974). In McFarland 
ment under such circumstances may constitute undue influence, but only if a confidential relationship existed at the time the agreement was signed, ${ }^{154}$ and current rules governing the termination of a confidential relationship render this an inadequate means to protect against such an unfair bargaining practice. ${ }^{150}$

Promises to reconcile are among the most exploitative of bargaining practices, since they entail an abuse of the most intimate knowledge of the spouse's psychological weaknesses. They are also designed to produce, and do regularly result in, patently unfair agreements. ${ }^{108}$ Therefore, in those states that mandate substantive reviews for fairness or unconscionability, parties victimized by such unfair practices may sometimes be relieved of the consequences of their good faith and naiveté. ${ }^{157}$ Absent such review standards, however, most courts are inadequate to the task of expanding traditional contract defenses, or of fashioning a new remedy, to encompass misleading promises of reconciliation.

Particularly in view of the states' great interest in the preservation of marriage, it is ironic that a spouse who has genuinely, if foolishly, tried to promote a reconciliation should be penalized by being held to the terms of an unfair bargain. Given the apparent ineffectiveness of traditional contract defenses as a remedy against such practices, it is also unfortunate that promises to reconcile have not received serious judicial consideration as an independent ground for setting aside a settlement agreement. ${ }^{168}$ Factual circumstances supporting the allegation

v. Reynolds, 513 S.W.2d 620 (Tex. Civ. App. 1974), a husband promised his wife he would remarry her within two weeks if she signed an agreement giving him custody of the children and all community property. The decree was set aside, but on the ground that the misrepresentation of assets constituted fraud. But in In re Marriage of Hawkins, 106 Ill. App. 3d 68, 70, 435 N.E.2d 786, 788 (1982), a decree was set aside as unconscionable, where there was proof, among other things, that the husband's promise to "start over" had been made at a time when he was seeing another woman.

154 See, e.g., Francois v. Francois, 599 F.2d 1286 (3d Cir. 1979) (wife's domination of husband while in confidential relationship constituted undue influence); Bradshaw v. Bradshaw, 578 P.2d 762 (Okla. Ct. App. 1977) (undue influence found where confidential relationship was coupled with misrepresentation); Marshall v. Marshall, 273 S.E.2d 360 (W. Va. 1980).

${ }_{155}$ See supra text accompanying notes 76-82; see also Murphy v. Murphy, 34 N.C. App. 677, 239 S.E.2d 597 (1977), rev'd on other grounds, 295 N.C. 390, 245 S.E.2d 693 (1978). Murphy held that a reconciliation promise could not constitute undue influence because the wife/promisee was represented by an attorney.

168 See cases cited supra notes 148 \& 153.

187 See, e.g., Demaggio v. Demaggio, 317 So. 2d 848 (Fla. Dist. Ct. App. 1975) (agreement set aside where husband promised that if wife signed agreement, there would be a reconciliation); In re Marriage of Hawkins, 106 Ill. App. 3d 68, 435 N.E.2d 786 (1982) (promise of reconciliation to urge spouse to sign settlement agreement would be reason for a finding of fraud).

${ }^{168}$ In some states, if the promise to reconcile actually results in an attempt to 
that a promise was made in order to induce the agreement, coupled with unfairness of terms, should form an adequate basis for relief from such a settlement, particularly prior to its incorporation into a decree. ${ }^{168}$

Traditional contract remedies have also proved inadequate to deal effectively with what is probably the single most troubling, albeit powerful, form of coercive bargaining conduct-the use of threats to sue to procure inequitable settlement agreements. These threats may be directed at the other spouse, for custody, or at a third party, usually for alienation of affections. In either instance, their use creates a gross imbalance of bargaining strength between the parties, an imbalance that may be exploited with impunity in most family law cases.

It is axiomatic that only "wrongful acts" depriving one of the exercise of his or her free will can constitute duress, ${ }^{100}$ and that the threat to do what one has a legal right to do is rarely such a wrongful act. ${ }^{161}$ In recent years, however, courts have considerably softened this traditional rule by accepting the principle that a threat may be lawful, but nevertheless sufficiently "wrongful" in a moral sense, if undertaken for a collateral purpose. Thus a contract procured by such means may be set aside. ${ }^{162}$

reconcile, the executory provisions of the agreement may well be voided in any event. 1 A. LINDEX, supra note $2, \S 15$, at 15-133; see also H. GLARK, supra note 3 , $\S 16.7$, at 542. In many states, however, an agreement will survive a resumption of cohabitation between spouses, unless there was a genuine intent to reconcile. See Wadlington, Sexual Relations after Separation or Divorce: The New Morality and the Old and New Divorce Laws, 63 VA. L. Rev. 249, 261 (1977); see also In re Marriage of Reeser, 635 P.2d 930 (Colo. App. 1981); Peterson v. Peterson, 583 S.W.2d 707, 710 (Ky. App. 1979). Thus courts have already had to deal with the problem of determining if there had been a genuine intent to reconcile.

${ }_{169}$ That a brief reconciliation ensued following execution of the agreement, for example, is strong evidence that a promise was in fact made. See, e.g., Francois v. Francois, 599 F.2d 1286 (3d Cir. 1979) (wife persuaded husband to sign settlement agreement by promise of reconciliation; one-year reconciliation indeed subsequently followed); Marshall v. Marshall, 273 S.E.2d 360 (W. Va. 1980); see also Bradshaw v. Bradshaw, 578 P.2d 762 (Okla. Ct. App. 1977).

16013 S. WiLliston, supra note 67, §1606, at 658.

161 See, e.g., Blalock v. Blalock, 51 Ala. App. 686, 288 So. 2d 747 (1974) (threat to take property disposition issues to court unless settlement is made is not coercive); cases cited infra note 177.

16213 S. WiLliston, supra note $67, \S 1606$, at 672; see also Kaplan v. Kaplan, 25 Ill. 2d 181, 182 N.E.2d 706 (1962); Bell v. Bell, 38 Md. App. 10, 379 A.2d 419 (1977); Link v. Link, 278 N.C. 181, 179 S.E.2d 697 (1971). Courts have been more willing to expand the classic definitions of duress and undue influence to include "morally" wrongful acts in other areas of the law than in domestic cases. See, e.g., Bayshore Ind., Inc. v. Ziats, 232 Md. 167, 192 A.2d 487 (1963); Wise v. Midtown Motors Inc., 231 Minn. 46, 52, 42 N.W.2d 404, 407-08 (1950) (employee release was signed under threats, and the court held that "one has no right to threaten another, in order to accomplish an ulterior purpose, with a groundless action or with an action to enforce some just legal demand where the purpose is not to enforce the demand, but rather . . . 
For several reasons, however, this principle has not received application in family law cases, where threats to institute civil actions in order to procure a favorable alimony or property settlement do not constitute duress. ${ }^{163}$ Courts have firmly adhered to this rule where the alleged wrongful act consists of a threat to sue a third party for alienation of affections. ${ }^{164}$ "[A] threat of personal embarrassment," as one court noted, "does not rise above" the level of "annoyance and vexation."16s

Several factors account for this failure of traditional contract law to deal effectively with such coercive tactics. Unwillingness to label such threats as "wrongful" derives in part from the fact that the threatened act is indeed lawful in states where such heart-balm actions persist. ${ }^{168}$ As noted previously, there is a general reluctance to undo a bargain reached through the strategic use of sanctioned bargaining "endowments," even though the resulting contract may be quite unfair. ${ }^{\mathbf{1 0 7}}$ There are, in addition, very real difficulties, in such a fact-sensitive area as duress, in proving that the threats were made for the collateral and improper purpose of coercing the agreement. ${ }^{168}$ Refusal to redress the results of such overreaching tactics, moreover, may reflect the continuing role of fault in the alimony and property division laws of some states, ${ }^{16 \theta}$ and it may also reflect a judicial tolerance for the use of such

to so use the legal process as to oppress his adversary and to cause him unnecessary hardship"); Mitchell v. C.C. Sanitation Co., 430 S.W.2d 933 (Tex. Civ. App. 1968). 163 See infra note 177.

164 See, e.g., Kaplan v. Kaplan, 25 Ill. 2d 181, 182 N.E.2d 706 (1962) (threat to sue held not coercive). But see Bell v. Bell, 38 Md. App. 10, 379 A.2d 419 (1977), discussed infra note 184.

${ }^{185}$ Kaplan v. Kaplan, 25 Ill. 2d 181, 188, 182 N.E.2d 706, 710 (1962). In this case, a wife's threat to sue for alienation of affections and to publicize photographs of her husband with another woman was held not to constitute a "wrongful" threat.

${ }_{168}$ Various types of heart-balm causes of action are still available in several states. Simonye v. Nelson, 510 F. Supp. 946 (1981); Hunt v. Chang, 60 Hawaii 608, 594 P.2d 118 (1979); Landholm v. Webb, 69 Idaho 204, 205 P.2d 507 (1949); Doe v. Doe, 390 N.E.2d 730 (Mass. 1979); Sipe v. Farmer, 398 So. 2d 1325 (Miss. 1981); Hale v. Buckner, 615 S.W.2d 97 (Mo. Ct. App. 1981); Kremer v. Black, 201 Neb. 467, 268 N.W.2d 582 (1978); Thompson v. Chapman, 93 N.M. 356, 600 P.2d 302, (1979); Scott v. Kiker, 59 N.C. App. 459, 297 S.E.2d 142 (1982); Holston v. Jackson, 278 S.C. 137, 292 S.E.2d 142 (1982); Head v. Newton, 396 S.W.2d 209 (Tex. Giv. App. 1980); Nelson v. Jacobsen, 669 P.2d 1207 (Utah 1983); ARK. STAT. ANN. § 73-201 (Supp. 1980).

167 The term is from Mnookin \& Kornhauser, supra note 17, at 966.

108 See infra text accompanying notes 179-84.

169 According to Freed and Foster, 15 states regard fault as a factor which may be considered in alimony or property division awards. That list fails, however, to include North Carolina, where alimony (but not property division) continues to be wholly fault-based. N.C. GEN. STAT. \$ 50-16.2 (1976). However, the tendency is to minimize the significance of fault, and in 19 states fault is specifically excluded as a factor that may be considered with alimony or property division. See Freed \& Foster, supra note 145 , at $4083-86$. 
tactics between spouses. ${ }^{170}$

Such explanations, however, do not sufficiently justify the continued tolerance of threats that create bargaining strengths, and exploit bargaining weaknesses, in a manner that undermines the very essence of the bargaining process. When the threatened act is a custody suit, moreover, the inadequacies of the current system are thrown into even sharper relief.

Custody determinations are often the most critical part of any negotiated settlement. Professors Mnookin and Kornhauser have argued persuasively that "it is possible to reduce the concerns of divorce bargaining into two elements: money and custody."171 In their excellent study of divorce bargaining, the authors also point out the obvious: that "over some range of alternatives, each parent may be willing to exchange custodial rights and obligations for income or wealth."172 And, indeed, a certain amount of horse-trading involving children and money occurs in most dissolutions. ${ }^{173}$

In some instances, however, it is apparent that custody threats are made for the primary or sole purpose of coercing unduly favorable settlements from a spouse. Such a threat may easily signal an abrupt end to any real "bargaining" between the parties. The testimony of one wife that "I would have signed a pact with the Devil if I'd have had to to keep my children," " is probably not atypical. ${ }^{174}$ Although these tactics, which can produce such a response in the mind of the victim, would appear to epitomize the deprivation of free will that lies at the heart of the concept of duress, ${ }^{175}$ the law of duress has proved inade-

170 Direct support for such a proposition is basically not available, although it might not be unreasonable to infer such a conclusion from the almost casual manner with which most courts dismiss such allegations, particularly in the context of threats to sue for custody. See infra notes 176-184; cf. Olsen, supra note 1, at 1504-07 (discussion of traditional state rationale for nonintervention in the family). It is possible to speculate that, in a fashion analogous to the way the judicial system once regarded interspousal violence, there may in fact be a greater tolerance for bargaining behaviors between spouses that would not be acceptable between other parties. For the policy reasons behind the state's nonintervention in such matters as interspousal violence, see H. GLARK, supra note $3, \S 9.1$, at 253 .

${ }^{121}$ Mnookin \& Kormhauser, supra note 17, at 963.

172 Id. at 964 .

173 The phrase "horse-trading" was used derisively by the court in In re Marriage of Gonzalez, 57 Cal. App. 3d 736, 746, 129 Cal. Rptr. 566, 572 (1971).

${ }_{174}$ In re Marriage of Gonzalez, 57 Cal. App. 3d 736, 746, 129 Cal. Rptr. 566, 571 (1971) (duress found where husband threatened to harm wife and illegally remove children from country).

178 Williston has noted that three elements are common to situations wherein duress has been found to exist: "(1) that one side involuntarily accepted the terms of another; (2) that circumstances permitted no other alternative; and (3) that the circumstances were the result of the coercive acts of the opposite party." 13 S. WILLISTON, supra note $67, \S 1603$, at 665 . 
quate to remedy the result of such bargaining conduct.

Although it may be possible in some states to set aside agreements procured by the use of such threats on the grounds of unfairness or unconscionability, ${ }^{176}$ courts have more commonly refused to provide relief on the traditional ground that "insisting upon using the courts to substantiate what one believes to be his legal rights is not coercive."177 Occasionally, the frequency with which custody threats are employed as a bargaining weapon has been a factor in the denial of relief. ${ }^{178}$ It would seem logical also to infer that courts are reluctant to saddle themselves with the task of distinguishing a genuine threat to sue for custody from a threat prompted by a wrongful and collateral purpose. ${ }^{179}$

An important North Carolina case illustrates the difficulties inherent in drawing this distinction in a family law context and the resulting inadequacies of standard duress principles. In Link $v$. $\operatorname{Link}^{180}$ a wife's transfer of separate property to her spouse was set aside on the grounds of duress, where the husband had threatened to sue for custody if the wife did not agree to the transaction. The Supreme Court of North

${ }^{178}$ See In re Marriage of Carlson, 101 Ill. App. 3d 924, 428 N.E. 2d 1005 (1981), where a father's threats to take children from his spouse formed part of the basis for setting aside an agreement on the ground of unconscionability; see also Pegram v. Pegram, 310 Ky. 86, 219 S.W.2d 772 (1949).

${ }_{177}$ Zeeb v. Zeeb, 76 Ill. App. 3d 894, 897, 395 N.E.2d 660, 662 (1979). See also Libel v. Libel, 5 Kan. App. 2d 367, 616 P.2d 306 (1980); In re Marriage of Baker, 584 S.W.2d 449 (Mo. Ct. App. 1979); In re Marriage of Lawrence, 642 P.2d 1043 (Mont. 1982).

${ }^{178}$ One court commented, for example, that holding custody threats to constitute duress "would expose many separation agreements to attack and worse, would not be based upon any kind of a realistic understanding of preagreement negotiations." In re Marriage of Lawrence, 642 P.2d 1043, 1049 (Mont. 1982). In Johnson v. Johnson, No. 82 CVD0688 (N.C. Ct. App. Mar. 20, 1984), the very frequency with which the husband had made threats to sue for custody and expose his wife's previous abortion was a factor in the court's decision that she had not been under duress at the time the separation agreement was signed. It is highly probable, moreover, that the reported cases dealing with this issue are but the tip of the iceberg. Additionally, the increasing frequency with which fathers do sue for custody, and win, undoubtedly makes such a threat more effective than it might have been in the past.

178 Custody threats whose main or sole purpose is to coerce unfair settlement agreements, of course, should be distinguished from those instances in which a party genuinely considers suing for custody. Although this Article cannot fully discuss how such distinctions could be drawn, it seems likely that a parent who, in an effort to promote the child's best interest, considers suing for custody would not abandon the idea solely in order to procure an unduly advantageous settlement. $C f$. Sharp, supra note 44, at 1280 (in a divorce, parents usually consider the child's welfare). It should also be noted that courts are regularly confronted with the need to make similarly difficult determinations in other areas of the law, as, for example, concerning the genuineness of a claim for emotional distress. See W. PROSSER, HANDBOOK OF THE LAW OF ToRTs, $\S 54$, at 327-35 (4th ed. 1971).

180278 N.C. 181,179 S.E.2d 697 (1971). 
Carolina observed that such a threat might be unlawful because of a "corrupt intent."

[T] ]he act done or threatened may be wrongful even though not unlawful, per se; and . . . the threat to institute legal proceedings . . . which might be justifiable, per se, becomes wrongful, within the meaning of this rule, if made with the corrupt intent to coerce a transaction grossly unfair to the victim and not related to the subject of such proceedings. ${ }^{\mathbf{3 1}}$

The limitations of this well-stated "corrupt intent" rationale for typical domestic law situations, however, became evident with the court's further observation that a threat to sue for custody "would not, per se, constitute duress when the transaction induced by such statement of intent was the execution of a separation and custody agreement."182 That situation, explained the court, is "completely different" from the case wherein "the threat to take the children from the wife is for the purpose of coercing her into transferring, without consideration, her individual property to the husband."18s Thus the principle by which duress can encompass morally wrongful acts is of limited utility, for family law purposes, so long as the necessary "corrupt intent" is identified with the procurement of an "unrelated" transaction and so long as custody and settlement agreements are deemed related. ${ }^{184}$ This is not to suggest that duress principles could not be expanded to accommodate such tactics; elimination or reinterpretation of the "unrelated" or collateral purpose requirement would be welcome developments indeed. In family law, however, such developments are not occurring.

The only notable departure from this approach appears in a California decision, In re Marriage of Gonzalez, ${ }^{188}$ in which the court held

181 Id. at 194,179 S.E.2d at 705.

182 Id. at 195, 179 S.E.2d at 705. Moreover, the Link court found that the husband and wife were in a confidential relationship at the time the transfer was coerced. Id. at 193,179 S.E.2d at 704.

183 Id. at 195,179 S.E.2d at 705.

184 In Bell v. Bell, 38 Md. App. 10, 379 A.2d 419 (1977), a husband threatened to publicize his wife's adulterous relationship if she did not agree to a property settlement his attorney had drawn up. Because Maryland courts did not have jurisdiction to divide property in divorce actions at that time, the court found that the threats of civil suits were "unrelated" to the dispute over property. Id. at 16-17, 379 A.2d, at 423-24. Ultimately, however, the court found that the wife had not been deprived of her free will. The Link and Bell decisions were also relied upon to set aside a separation agreement on the ground of duress in Eckstein v. Eckstein, 38 Md. App. 506, 379 A.2d 757 (1978). In that case, however, the husband had denied his wife access to a lawyer, to the children, the marital home, money, clothes, and transportation, and the wife was under psychiatric treatment at the time. Id. at 517, 379 A.2d at 763-64.

${ }_{185} 57$ Cal. App. 3d 736, 129 Cal. Rptr. 566 (1971). The wife was represented by counsel in this case. 
that a husband's threat to sue for custody unless his wife signed a settlement agreement could constitute duress.

[The husband] contends there can be no duress as a matter of law when a wife bargains away substantial property rights to protect her custody rights to the children. It is not . . a classic example of a threat to use legal processes in order to settle a legal problem. The involvement of the children that automatically raises the issue of their welfare places this type of litigation in an arena of its own. The emotions and fears of the parties are more intense and are not comparable to litigants in a normal civil action. If threatened use of a custody hearing can cause so much fear in the mind of the responding parent that contractual volition is destroyed, the court is not required to legally recognize the agreement when equity demands otherwise. ${ }^{186}$

It is significant that Gonzalez is the only case that, by its focus on the children's interests, questions the law's continued tolerance of custody for money bargains. Unfortunately, it also stands virtually alone in its willingness to recognize the extent to which the use of such threats can effectively deprive a party of the exercise of free will, without regard to whether or not the transaction induced was "related" to the threat. ${ }^{187}$

Thus it is difficult to avoid the conclusion that standard contract principles have been seriously inadequate to provide remedies for parties coerced into execution of unfair agreements through custody threats and reconcilation promises. Undoubtedly, this is due in part to judicial reluctance to expand the law of undue influence and duress to encompass such bargaining tactics, and to the real difficulties in proving that such tactics were employed for corrupt or wrongful purposes. The use of such unfair bargaining techniques between husbands and wives, however, is an excellent example of the "imperfect" market in which Professor Eisenberg has argued that the standard bargaining principle is inadequate. ${ }^{188}$ As noted previously, dissolution of the husband-wife relationship is hardly the classic, perfectly competitive market in which such a principle was designed to operate. Indeed, such threats or promises would appear to constitute an excellent example of what that

${ }^{188}$ Id. at 747-48, 129 Cal. Rptr. at 572-73.

187 It has been met with a relatively hostile reception by the few courts which have discussed it at all. See, e.g., In re Marriage of Lawrence, 642 P.2d 1043, 1047 (Mont. 1982), discussed supra note 178.

${ }_{188}$ See Eisenberg, supra note 135, at 799. Professor Eisenberg argues that as a contract situation moves from that of a perfectly competitive market, fairness and efficiency considerations, which support the bargain principle, will become attenuated. Id. 
author has identified as an "unfair persuasion" technique- "the use of bargaining methods that seriously impair the free and competent exercise of judgment and produce a state of acquiescence that the promisee knows or should know is likely to be highly transitory." 189 Neither the traditional "protective" principles of family law nor principles of contract law, at least insofar as they have received application in family law, provide an adequate safeguard against, or remedy for, such patently unfair bargaining tactics.

\section{Summary}

There are substantial defects in the procedural principles that govern the execution and enforcement of settlement agreements. The traditional protective system is at best a double-edged sword: particularly with regard to the confidential relationship, it offers a considerably greater illusion of protection than it in fact affords. Standard contract principles are often inadequate to deal with the unique opportunities for overreaching that exist between husbands and wives, and more recently developed and more flexible applications of contract defenses are also insufficient.

Thus disclosure duties are still closely linked to the easily dissipated confidential relationship, with the result that greater duties of fair dealing and disclosure are imposed upon business partners and funeral directors than upon divorcing spouses, ${ }^{180}$ and unduly heavy burdens are placed upon spouses who seek to set aside agreements or decrees based upon fraud. Bargaining tactics, such as custody threats and reconciliation promises, whose sole function is to procure substantially unfair agreements are often employed with impunity, and thus slip through holes in the law of fraud, duress, and undue influence.

It is possible to devise strictly "procedural" principles to provide a partial remedy to many of these problems. Clearly, imposition of independent duties of disclosure and development and application of more

188 Id. at 773-74. Arguing that traditional contract defenses to the bargain principle, such as duress, go to the bargaining process, not to its outcome, and that they do not address problems in less than competitive markets, Professor Eisenberg advocates an expansion of the "unconscionability paradigm." Id. at 752-54. For Professor Eisenberg, unconscionability should be expanded to address the "quality" or substance, not the process, of the bargain. Id. at 754. He thus identifies bargaining problems, such as unfair persuasion, that this expanded notion of unconscionability will remedy. According to Professor Eisenberg, unconscionability will not replace the bargain principle as the foundation of contract law, but it may well absorb the traditional defenses to this principle because of its emphasis on the overall quality of the bargain. Id. at 799 .

${ }_{100}$ See supra text accompanying note 102; note 126 and accompanying text. 
flexible contract defenses ${ }^{191}$ are essential reforms that could eliminate many inequitable results. Contracts between husbands and wives, however, are different from virtually all other kinds of contracts, and standard contract principles often operate with neither efficiency nor effectiveness in such a context. Defects in the current system may not be adequately addressed so long as fair bargaining is defined, not by its result, but by its processes.

\section{Substantive FaIRNess}

\section{A. Fairness Standards and Judicial Review}

A comprehensive definition of a substantively fair or unfair settlement agreement is probably impossible to devise. ${ }^{192}$ For present purposes, however, a negative definition of the concept may suffice, in the sense that a fair agreement is one that is not unfair or unconscionable. And at a practical or functional level, there does appear to be general agreement that unfair marital contracts can be identified: in a broad sense, unfair agreements are those in which one party has received disproportionately more or less than what a court would have been likely to have ordered absent agreement between the parties. ${ }^{193}$

Moreover, an agreement procured by fraud, duress, or other forms of procedural overreaching or unfair persuasion techniques is almost certain to be substantively "unfair" in this sense. But the reverse proposition is not true: given current standards governing the process of contracting, an agreement may be substantively unfair, but nonetheless enforceable, since it may well not have been the product of any legally cognizable form of unfair bargaining practices. Thus, technically "fair" procedural standards hardly constitute a guarantee of fair results.

As noted previously, this gap between fair procedures and fair results could be greatly narrowed by imposition of rigorous and independent disclosure duties and by expansion of the law of fraud and duress to encompass such unfair persuasion techniques as reconciliation promises or custody threats. Indeed, it seems likely that parties who were fully aware of their rights and who were not subjected to unfair

101 See, e.g., Shultz, supra note 17, at 333 ("The evolving tradition of contractual ordering very closely tracks crucial values emerging in modern marriage.")

${ }_{102}$ But see infra text accompanying notes $251-60$ for suggestions as to means whereby unfair agreements may be more easily identified.

${ }_{183}$ See, e.g., Prochazka v. Prochazka, 198 Neb. 525, 527, 253 N.W.2d 407, 409 (1977) ("Ithe agreement is not] obviously excessive in respect to benefits or burdens on either side"); Harder v. Harder, 49 Or. App. 582, 619 P.2d 1367 (1980); see also Schultz, supra note 17 , at 282 . Thus fairness can only be defined with reference to the substantive law of a particular state. 
persuasion tactics would agree to accept disproportionate benefits and burdens only in the rarest of circumstances. ${ }^{104}$

The distinction between restructuring the bargaining process to guarantee a significant likelihood of fair results and imposition of a substantive fairness standard, however, is far more than semantic. ${ }^{195}$ In the first place, substantive review for fairness is necessary in order to ensure compliance with procedural standards, however well- or ill-developed those standards may be. More importantly, procedural standards, by their very nature, cannot adequately bear the burden of producing fair results in such an imperfect and noncompetitive market as divorce. ${ }^{198}$ Fair results, therefore, can be reliably produced only by imposition of meaningful reviews for substantive fairness prior to merger or incorporation. After a final decree had been entered, such a standard would be inappropriate. Res judicata principles, moreover, would be better served by a system of judicial review sufficiently efficient to prevent merger or incorporation of unfair agreements.

One important distinction must be made at the outset of this discussion: the extent to which courts may undertake substantive reviews for fairness is different from the extent to which they actually do so. The former issue raises several interesting problems.

As noted previously, most states require that private agreements undergo some type of judicial approval process, and most courts are not bound to accept or approve agreements thus submitted to them. ${ }^{192}$ In many states such agreements are, by statute or decision, "merely evidence" that, together with any other relevant evidence of the circum-

106 The experience of most practitioners would confirm this author's impression that parties agree to disproportionate distributional consequences largely from ignorance and a lack of genuine understanding of their rights. As one court noted, it was "inconceivable" that an agreement, which gave the wife $\$ 500$ as well as $\$ 25$ monthly for support in exchange for a release of her interest in the family's house, lot, car, and all other property, would be made if parties were fully informed. McCarty v. McCarty, 300 S.W.2d 394, 402 (Mo. 1957). See also Grosz v. Grosz, 506 P.2d 46, 47 (Wyo. 1973), where the court expressed similar doubts. Where there are good reasons for such disproportion, however, the parties' agreement should be respected. See infra text accompanying note 255 .

${ }_{103}$ But see Eisenberg, supra note 135, at 800 (with the development of the uncon- . scionability concept the distinction between procedural and substantive standards may disappear).

${ }_{196}$ As Professor Eisenberg has aptly observed, "that a market is less than perfectly competitive does set the stage for transactions in which the bargain principle loses much or all of its force, because it is supported by neither fairness nor efficiency." Eisenberg, supra note 135 , at 799 . In the paradigmatic contractual relationship as found in a perfectly competitive market, procedural standards may be adequate to ensure fairness. However, substantive, not procedural, standards are needed to guarantee fairness in less than competitive markets. Id. at 799.

${ }_{107}$ See supra notes 34-36 and accompanying text; see also H. CLARK, supra note 3 , $§ 16.10$, at $548-53$. 
stances of the parties, a court may consider in determining the distributional consequences of the dissolution. ${ }^{198}$ It is also frequently said that such agreements are entitled to considerable judicial deference, ${ }^{109}$ and clearly they should not be rejected "arbitrarily or based upon a whim or because the court believes it could write a better agreement."200 In a growing number of states, however, courts are required to accept the parties' agreement, absent evidence of fraud, duress, overreaching, or a determination of unconscionability. ${ }^{201}$ Many courts apparently view this as an extension of their obligations to encourage the use of separation agreements. ${ }^{202}$ It also reflects the decreasing role of the state in the dissolution process and concomitant increase in the freedom of spouses to determine for themselves the distributional consequences of their dissolution. ${ }^{203}$

Clearly all of these standards mandate that judicial approval be withheld from agreements that were the product of procedurally unfair bargaining tactics. The degree to which a court may review for substantive fairness, however, can only be ascertained in cases wherein the issue is phrased as one of "unfairness alone." Such a review would occur where the issue is whether judicial discretion may be exercised to set aside an agreement containing a disproportionate distribution of benefits and burdens without proof of fraud, concealment, or traditional overreaching tactics.

In many instances, inequality of terms, or even gross dispropor-

198 See, e.g., Dawkins v. Dawkins, 172 So. 2d 633 (Fla. Dist. Ct. App. 1965); In re Marriage of Frey, 23 Or. App. 25, 541 P.2d 145 (1975); Perry v. Perry, 183 Tenn. $362,366,192$ S.W.2d 830, 831 (1946) (agreements "are regarded as merely furnishing evidence upon which the court will fix the . . . award"); Pearson v. Pearson, 561 P.2d 1080 (Utah 1977).

${ }^{199}$ See, e.g., Zakoor v. Zakoor, 240 So. 2d 193 (Fla. Dist. Ct. App. 1970); Peterson v. Peterson, 85 N.J. 638, 428 A.2d 1301 (1981); Pearson v. Pearson, 561 P.2d 1080 (Utah 1977).

${ }^{200}$ Stockton v. Stockton, 435 N.E.2d 586, 589 (Ind. Ct. App. 1981). See also Strope v. Strope, 131 Vt. 210, 216, 303 A.2d 805, 809 (1973) ("mere statement by the court that it is dissatisfied with the stipulation is an insufficient basis for rejecting any of the terms of the agreement").

${ }_{201}$ See statutes cited supra notes 35-36; see also Bailey v. Bailey, 300 So. 2d 294 (Fla. Dist. Ct. App. 1975); In re Marriage of Lorenzi, 84 IIl. App. 3d 427, 405 N.E.2d 507 (1980); Kline v. Kline, 92 Mich. App. 62, 284 N.W.2d 488 (1979); Hopkins v. Hopkins, 591 S.W.2d 716 (Mo. App. 1979); Tureman v. Tureman, 620 P.2d 1200 (Mont. 1980); Lyall v. Lyall, 240 Pa. Super. 649, 361 A.2d 367 (1976); Morgan v. Morgan, 622 S.W.2d 447 (Tex. App. 1981); Strope v. Strope, 131 Vt. 210, 303 A.2d 805 (1973).

${ }_{202}$ See, e.g., Le Bert-Francis v. Le Bert-Francis, 194 A.2d 662, 664 (D.C. 1963); Christian v. Christian, 42 N.Y.2d 63, 72, 365 N.E.2d 849, 855, 396 N.Y.S.2d 817, 823 (1977); UnIF. MarRIage AND DrvorCe ACr § 306, 9A U.L.A. 135 (1979). Homer Clark approves this trend in the states. See H. CLARK, supra note $3, \S 16.10$, at 550. ${ }^{208}$ See Mnookin \& Kornhauser, supra note 17, at 953-54. 
tionality of terms, is insufficient to warrant setting aside an agreement in the absence of fraud, duress, overreaching, or concealment. ${ }^{204} \mathrm{~A}$ common modification of this approach is the rule, adopted in many states, that an agreement that is "unfair on its face"20s will create an inference that fraud, duress, or some other form of overreaching has occurred. ${ }^{208}$ The burden of proving the validity of the contract is then shifted to the party seeking to enforce it. ${ }^{207}$ Underlying this approach is an implicit recognition that patently unfair agreements are almost never the product of equal knowledge and good faith bargaining practices. In the relatively few instances in which courts held that substantive unfairness alone will suffice to invalidate an agreement, moreover, there are usually clear indications that the bargaining process was in fact tainted either by the misconduct of one of the spouses, ${ }^{208}$ or by the fact that one

204 In re Estate of Vai, 65 Cal. 2d 144, 153, 417 P.2d 161, 168, 52 Cal. Rptr. 705,710 (1976) (even a "grossly disproportionate" division of property not sufficient to void agreement for lack of consideration) (but see In re Marriage of Moore, $113 \mathrm{Cal}$. App. 3d 22, 169 Cal. Rptr. 619 (1980)); Reynolds v. Reynolds, 415 A.2d 535, 537 (D.C. 1980) ("In the absence of fraud, duress, concealment . . . an agreement is valid . . . no matter how ill-advised a party may have been in executing it."); Peterson v. Peterson, 583 S.W.2d 707, 711 (Ky. App. 1979) (party must show "some evidence of fraud, undue influence, overreaching" before relief will be available, and agreement "could not be held unconscionable solely on the basis that it is a bad bargain."); Eckstein v. Eckstein, $38 \mathrm{Md}$. App. 506, 379 A.2d 757 (1978); In re Marriage of Hansen, 31 Or. App. 823, 829, 571 P.2d 568, 571 (1977) ("disproportionate" agreement upheld absent proof of "misconduct or overreaching").

${ }^{203} 1 \mathrm{~A}$. LiNDEY, supra note $2, \S 15$, at $15-93$. It is difficult to understand, however, how an initial judgment that an agreement is "fair on its face" can be made unless the court has before it the necessary information on the financial and other circumstances of the parties, and unless it undertakes some preliminary form of review.

${ }^{208}$ According to Williston, a "disproportionate exchange of values" is a "significant indication of coercion." 13 S. WILLISTON, supra note $67, \S 1617$, at 707. See also Baker v. Baker, 394 So. 2d 465, 466 (Fla. Dist. Ct. App.), cert. denied, 402 So. 2d 607 (Fla. 1981) (agreement unfair on its face raises presumption of concealment and shifts burden of proof to party seeking enforcement); Le Bert-Francis v. Le Bert-Francis, 194 A.2d 662, 664 (D.C. 1963) (agreement may be "so unfair and unreasonable as to raise a presumption of invalidity"); Christian v. Christian, 42 N.Y.2d 63, 73, 365 N.E.2d $849,856,396$ N.Y.S.2d 817, 824 (1977) (requiring proof of unfairness plus overreaching, but suggesting that courts may look for "an inference" or even a "negative inference" of overreaching with separation agreements); Davis v. Davis, 24 Ohio Misc. 17, 258 N.E.2d 277 (1970) (burden of proof shifts where terms are disproportionate); Bradshaw v. Bradshaw, 578 P.2d 762 (Okla. Ct. App. 1977) (grossly unfair terms-husband received custody of children and $\$ 80,000$ in property, while wife received a used car, personal effects, and $\$ 11.21$ in bank account-indicate undue influence). Under the newly enacted N.Y. Dom. Rel. Law $\S 236(\mathrm{~b})(3)$ (McKinney Supp. 1983), a court must now consider if the terms were "fair and reasonable at the time of the making of the agreement and are not unconscionable at the time of entry of final judgment." See Tuckman v. Tuckman, 112 Misc. 2d 803, 447 N.Y.S.2d 654 (1982).

207 See cases cited supra note 206.

${ }^{208}$ Sande v. Sande, 83 Idaho 233, 241, 360 P.2d 998, 1003 (1961) (reaffirming the rule that where an agreement is "inequitable" to the wife, and it manifestly appears there has been overreaching on the part of the husband, a court has the power to 
party was not represented by an attorney. ${ }^{200}$ A significant exception, where the court found unfairness without any indicia of bargaining misfeasance, is the recent decision in In re Marriage of Manzo. ${ }^{\mathbf{2 1 0}}$ The Supreme Court of Colorado held that a property division could be set aside as unconscionable even though there was no finding that it was "procured by overreaching, concealment of assets, or sharp dealing not consistent with the obligation of marital partners to deal fairly with each other." Such clear holdings that "unfairness alone" will suffice to set aside an agreement are quite rare.

An unconscionability standard of review does provide a court with considerably greater freedom to inquire into the substantive fairness of an agreement. ${ }^{212}$ As one commentator has noted, the standard both "explains and justifies the limits that should be placed upon the bargain principle on the basis of the quality of a bargain." less be incorrect to identify that standard with a genuine substantive

set aside the decree even though it was not procured by fraud or duress, especially where the wife was ignorant of her rights and acted without counsel); In re Marriage of Hawkins, 106 Ill. App. 3d 68, 71, 435 N.E.2d 786, 788 (1982) ("unfair" agreement set aside absent showing of fraud, although facts clearly indicate some concealment of assets); Harrigan v. Harrigan, 135 Vt. 249, 250, 373 A.2d 550, 552 (1977) (agreement set aside where husband took "unconscionable advantage" of circumstances of wife).

${ }^{209}$ Gelfo v. Gelfo, 198 So. 2d 353 (Fla. Dist. Ct. App. 1967) (agreement, which contained a provision wherein the wife waived all alimony rights, set aside as unconscionable for lack of adequate consideration, with no testimony as to any fraudulent procurement, although wife was not represented by counsel); McCarty v. McCarty, 300 S.W.2d 394, 402-03 (Mo. 1957) (unfair agreement set aside based on court's conclusion that it was "inconceivable" that wife would have signed had she been fully informed by an independent attorney); D'Arc v. D'Arc, 164 N.J. Super. 226, 239, 395 A.2d 1270, 1277 (1978) (unfair agreement where wife did not consult her attorney), cert. denied, 451 U.S. 971 (1981).

210659 P.2d 669 (Colo. 1983) (en banc).

${ }^{211}$ Id. at 671. See also Gelfo v. Gelfo, 198 So. 2d 353 (Fla. Dist. Ct. App. 1967); Stockton v. Stockton, 435 N.E.2d 586, 589 (Ind. Ct. App. 1982) (court may enter order different from settlement agreement if record demonstrates "some unfairness, unreasonableness, manifest inequity in terms of the agreement, or that the execution of the agreement was procured through fraud, misrepresentation, coercion, duress, or lack of full disclosure"); Diers v. Diers, 185 Neb. 552, 556-57, 177 N.W.2d 503, 506 (1970) (upholding trial court, which had entered order different from separation agreement submitted to it, apparently because it found the agreement to be "unconscionable, or obtained through ignorance, passion or improvidence"); Hansen v. Hansen, 24 Wash. App. 578, 581, 602 P.2d 369, 371 (1979) (under state statute court may modify agreement if it finds it was unfair at the time of execution). All of these cases deal with separation agreements that were modified or set aside prior to incorporation or merger into a decree.

212 In addition to the UMDA states, New York has recently adopted an unconscionability standard. See supra note 206 . The use of unconscionability is not unfamiliar to many domestic courts. Florida courts, for example, make a consistent use of the concept. See Gelfo v. Gelfo, 198 So. 2d 353, 355 (Fla. Dist Gt. App. 1967); see also Bailey v. Bailey, 300 So. 2d 294, 296 (Fla. Dist. Ct. App. 1974).

213 Eisenberg, supra note 135, at 799. 
fairness test, since unconscionability may well be, and often has been, defined to require a showing of some traditional form of overreaching or other bargaining misconduct in addition to unfairness of terms. ${ }^{214}$ Indeed, despite the "protective" principles assumed to soften the application of contract law in this context, unconscionability has been interpreted with considerably greater restraint in family law than, for example, in consumer law. ${ }^{215}$

In general, therefore, "substantive" review, at least insofar as it encompasses review for fairness in results regardless of process, is illusory. Many courts presume that inquiry solely into the quality of a bargain is neither required nor desirable; and reliance upon the concept of unconscionability as a remedy for unfair results is, as a practical matter, not fully warranted.

Ultimately, however, the fact that a court's scope of review is limited to procedurally unfair tactics, is open to substantive fairness inquiries, or-as is most likely-partakes of a combination of the two approaches, may be of little significance. Judicial power to review without a commensurate duty to do so renders that power largely irrelevant. And despite insistent pleas to the contrary, most settlement agreements will rarely receive more than a perfunctory review by a court. $^{216}$ This is particularly true where one of the parties fails to make

224 Compare In re Marriage of Manzo, 659 P.2d 669, 673 (Colo. 1983) (unconscionability finding demands evidence of some overreaching, such as that which results from inequality of bargaining power, together with terms unreasonably favorable to one party) with In re Marriage of Lawrence, 642 P.2d 1043 (Mont. 1982) (court viewed agreement as conscionable, reviewing solely whether the property division was disproportionate). Illinois has defined an unconscionable bargain as one that is "improvident, totally one-sided or oppressive." In re Marriage of Carlson, 101 Ill. App. 3d 924, 930, 428 N.E.2d 1005, 1011 (1981) (citations omitted). Kentucky and Nebraska courts speak in terms of agreements that are "manifestly unfair and inequitable." Jackson v. Jackson, 571 S.W.2d 90, 92 (Ky. App. 1978) (citation omitted); Paxton v. Paxton, 201 Neb. 545, 548, 270 N.W.2d 900, 902 (1978); Weber v. Weber, 200 Neb. 659, 668, 265 N.W.2d 436, 442 (1978). See also Peterson v. Peterson, 583 S.W.2d 707, 712 (Ky. App. 1979), stating that an agreement could not be held unconscionable because it was a bad bargain, but that it could be set aside if there was fraud, undue influence, or overreaching.

New York has adopted the classic formulation of an unconscionable bargain from Hume v. United States, 132 U.S. 406, 411 (1889), as "one 'such as no [person] in his .. . senses and not under delusion would make on the one hand, and as no honest and fair [person] would accept on the other." "Christian v. Christian, 42 N.Y.2d 63, 71, 365 N.E.2d 849, 855, 396 N.Y.S.2d 817, 823 (1977) (bracketed material added by court).

${ }_{215}$ Cf. Ellinghaus, In Defense of Unconscionability, 78 Yale L.J. 757, 771 (1969), who notes that the "underprivileged consumer has become recognized as sui generis to a sufficient degree to warrant its institutionalization by way of a quasipresumptive pursuit of 'unconscionability' whenever he appears on the scene."

${ }_{216}$ See Mnookin \& Kornhauser, supra note 17, at 993; Rheinstein, supra note 22, at 437 (courts with overcrowded dockets rarely scrutinize agreements on their own mo- 
timely objection to approval or incorporation of an agreement. ${ }^{217}$ As noted previously, moreover, parties, especially those who have been victims of misrepresentation or concealment, or who are not represented by counsel, are often unaware of their spouse's wrongdoing until after a decree has been entered. ${ }^{218}$ In most agreement-based dissolutions one party will have waived entry of appearance in any event.

In many instances, however, courts have little or no duty to make inquiry into either the procedural or substantive fairness of agreements presented to them for approval. ${ }^{219}$ In Miller $v$. Miller, ${ }^{220}$ for example, the Supreme Court of Montana upheld a lower court's division of marital property in accord with the terms of the agreement between the parties, although the trial court was completely unaware of the extent or value of the marital property and thus could hardly have conducted a meaningful inquiry into its facial fairness. ${ }^{221}$ Similarly, an Illinois court of appeals held that, because the dissolution of the marriage was uncontested, there was no abuse of discretion where the trial court had approved a separation agreement, despite its failure to make any inquiry into the circumstances surrounding the execution of the agreement. ${ }^{222}$

Even where a clearly articulated judicial duty to scrutinize agreements is present, the practical result may unfortunately be the same. The Court of Appeals of Kentucky has supplied an all too accurate synopsis of the normal "approval" process.

tion); see also Peterson v. Peterson, 583 S.W.2d 707, 712 (Ky. Ct. App. 1979) (trial court held that, absent showing of misrepresentation or overreaching, it has no control over a voluntary agreement).

${ }^{217}$ Cf. Christian v. Christian, 42 N.Y.2d 63, 72, 365 N.E.2d 849, 855, 396 N.Y.S.2d 817, 823-24 (1977) (courts must exercise "strict surveillance" when "confronted" with an objection by a party to an agreement); Drawdy v. Drawdy, 275 S.C. 76, 77, 268 S.E.2d 30, 30 (1980) (holding that a court must scrutinize for fairness "where one party seeks to enforce and the other to repudiate" an agreement before incorporation).

${ }^{218} C f$. Rheinstein, supra note 22, at 437 (challenges to such contracts are usually only brought up in post-divorce proceedings).

219 See, e.g., Kerslake v. Kerslake, 609 P.2d 559, 560 n.1 (Alaska 1980) (holding that a court has no affirmative duty to examine property settlements for fairness where both parties are represented; yet court must make sure agreement was voluntary and made with full understanding); Carter v. Carter, 19 Cal. App. 3d 479, $97 \mathrm{Cal}$. Rptr. 274 (1971) (lesser duty on court to ascertain extent of community property where the parties have executed an agreement; yet court must still police agreement for fraud and involuntariness).

220616 P.2d 313 (Mont. 1980).

221 Id. at 317-18. The appellate court explained that "[i]t is not the province of this Court to alter decisions and agreements made between husband and wife in the absence of compelling injustice." Id. at 318.

222 In re Marriage of Lorenzi, 84 Ill. App. 3d 427, 431, 405 N.E.2d 507, 510 (1980). 
[With] the so-called "uncontested" divorce ... the trial court is presented with an agreement which, on its face at least, appears to be reasonable. Since the dissolution proceeding is "uncontested," the parties offer no proof of economic circumstances. Although the trial court could request such proof on its own motion, [the statute] does not require it to do so. Such a request is apparently rare, perhaps because the court views the case as agreed. The trial court then approves the agreement as conscionable without really knowing the underlying facts. ${ }^{223}$

The italicized portion of this passage is indeed a precise illustration of the fundamental problem: courts often do not know the underlying facts upon which their approval of agreements should be conditioned. Unless a court requires the parties to present information concerning the extent and value of all marital and separate property, length of the marriage, and any other circumstances made relevant by the laws of a particular state, it will inevitably lack the necessary foundation upon which to base any meaningful judgment as to the fairness of the agreement. ${ }^{224}$ Such information should be required whether or not both parties are present, and whether or not one party objects to approval of the agreement. ${ }^{225}$ It is of critical importance, moreover, where one party added).

${ }^{223}$ Peterson v. Peterson, 583 S.W.2d 707, 711 (Ky. Ct. App. 1979) (emphasis

224 Ky. Rev. Stat. $\S 403.180$ (Supp. 1982) is an example of a statute that allows a court to require such information of parties. Wyo. STAT. ANN. § 20-2-112 (1977) allows the court to "cause the attendance of either party and compel an answer under oath concerning his property, rights or interests, or money that he may have." Apparently, however, it is rare for courts to request such information.

In Drawdy v. Drawdy, 275 S.C. $76,78,268$ S.E.2d 30, 31 (1980), the appellate court reversed the trial court, which had validated a property settlement agreement, for failure to hear testimony or admit evidence on the relative financial standing and comparative wealth of the parties. The appellate court, moreover, recommended the use of a state family court rule, which required submission of a financial declaration statement at a hearing, to determine the fairness of settlement agreements.

Even the courts of New York, which have long resisted financial disclosure requirements, have come to a grudging recognition that "it may be necessary to consider the relative financial positions of the parties to determine whether, under the circumstances, the agreement was fair when made or, is unconscionable on the basis of the present situation of the parties." Oberstein v. Oberstein, 93 A.D.2d 374, 378 (N.Y. App. Div. 1983). This change in position is due to the passage of the New York Equitable Distribution Law. It not only requires fairness in the terms of an agreement at the time of the formation, but also that the terms be not unconscionable at the time of enforcement. N.Y. DoM. REL. LAW § 236 (McKinney Supp. 1983). This new provision has given the courts a basis upon which to request economic disclosure.

228 Such procedures would not be necessary with the shortened and summary divorce proceedings now available for couples without children or substantial marital assets in some states. See, e.g., Colo. Rev. STAт. \& 14-10-120.3 (Supp. 1983). 
has waived appearance or was not represented by counsel. ${ }^{226}$ Agreements reviewed solely on the basis of information contained therein will almost always be fair on their face. ${ }^{227}$

Once a decree has been entered, the fact that the court lacked knowledge of the circumstances of the parties or of the extent of marital property is largely irrelevant, as is the fact that the decree was based upon default or consent. The disadvantaged party must then bear the difficult burden of proving procedural defects that rise to the level of fraud to have the decree set. aside. ${ }^{228}$ In most instances, a perfunctory review of a settlement agreement binds the parties as effectively as litigation of the issues would have. ${ }^{229}$

Once again, therefore, the safeguards afforded by the application of what appears to be a substantive standard of review are often, and at best, illusory. Moreover, the application of a pro forma reviewing standard will have the further effect of undermining the very goals it was designed to promote. And despite the abundance of general "fairness" standards for review, there are apparently few states that give real substance to such judicial obligations by requiring that the record itself demonstrate an adequate basis for a finding of fairness or conscion-

${ }^{228}$ See, e.g., In re Marriage of Moore, 113 Cal. App. 3d 22, 27, 169 Cal. Rptr. 619,622 (1980) (where agreement is made without advice of legal counsel, court must carefully scrutinize it to prevent inequity). The same should be true where both parties are represented by the same attorney. See Klemm v. Superior Court, 75 Cal. App. 3d 893, 901, 142 Cal. Rptr. 509, 514 (1977) (court recognized that the validity of any agreement negotiated without independent representation of each of the parties is vulnerabie to attack as having been procured by overreaching, although on facts of this case, because there was no actual conflict of interest, the court viewed the agreement as acceptable). But see Levine v. Levine, 56 N.Y.2d 42, 48, 436 N.E. 2d 476, 479, 451 N.Y.S.2d 26, 29 (1982) (court upheld agreement despite the fact that same attorney represented both parties, ruling that "as long as the attorney fairly advises the parties of both the salient issues and the consequences of joint representation, and the separation agreement arrived at was fair, rescission will not be granted" (citation omitted)).

${ }_{227}$ This is, of course, the fundamental problem with the presently applied standard: although cursory review may identify agreements which are patently unfair, it cannot reliably identify fair agreements.

228 See supra note 46 . Where a financial affidavit is required that proves to have contained false information, however, fraud may be found. See, e.g., Casanova v. Casanova, 166 Conn. 304, 348 A.2d 668 (1974) (supreme court ordered a new hearing to determine a proper divorce settlement after husband had misrepresented his income in an affidavit required by state law).

228 In a few states, such a perfunctory review will constitute an abuse of discretion. Colorado courts for example, are required to review the provisions of a separation agreement for fraud, overreaching, concealment of assets, or sharp dealing. Then the courts must look at the economic circumstances that result from the agreement to determine whether it is fair and reasonable. They must not accept blindly the agreement's terms. In re Marriage of Manzo, 659 P.2d 669, 674 (Colo. 1983); see also Rojas v. Rojas, 595 S.W.2d 729, 734 (Mo. App. 1980) (state law requires Missouri courts to exercise discretion in determining whether or not to approve a separation agreement by considering the economic circumstances of the parties and the other relevant factors). 
ability. ${ }^{230}$ Without strict enforcement of judicial duties to review agreements, fairness requirements, regardless of how broadly or how narrowly they are interpreted, are apt to mean very little indeed.

\section{B. Practical Application of Fairness Standards}

There are at least four major objections to the imposition of meaningful review for substantive fairness that must be addressed. The first, that the existing combination of contract and traditional "protective" principles already provides sufficient safeguards, has already been discussed in considerable detail, ${ }^{231}$ and surely admits of at least some doubt at this point: The three remaining objections merit further attention. These are: (1) that the administrative costs of imposing and enforcing substantive review standards would be prohibitive; (2) that, for a variety of reasons, courts cannot devise reliable standards for fairness against which proposed agreements might be measured; and (3) that the state's interest in ensuring fair agreements should be subordinated to a greater societal and individual interest in promoting freedom of contract and finality of obligations.

The administrative burden rationale has never been particularly persuasive. Professor Eisenberg has argued eloquently, and in a very similar context, that although "[p]lacing limits on the bargain principle involves costs of administration ... . [f]ailure to place such limits involves still greater costs to the system of justice." ${ }^{\text {"232 }}$ As we have seen in family law cases, failure to ensure meaningful review standards, particularly in light of the fact that some judicial review is usually required, has had most unfortunate consequences. ${ }^{233}$ Some states, moreover, do impose meaningful judicial review for substantive fairness, apparently without creating unduly burdensome administrative costs. In Colorado, for example, judicial review requires a dual level of scrutiny: courts must "first review the provisions for fraud, overreaching, concealment

${ }^{230}$ See, e.g., Stockton v. Stockton, 435 N.E.2d 586, 589 (Ind. Ct. App. 1982) (record must demonstrate some unfairness in the terms of the agreement or some bargaining inequity before court could second-guess the parties, particularly when both are represented by counsel); Peterson v. Peterson, 583 S.W.2d 707, 712 (Ky. Ct. App. 1979) (agreement will not be set aside solely because it was a bad bargain; there must be evidence of bad faith bargaining, such as overreaching or fraud); Strope v. Strope, 131 Vt. 210, 303 A.2d 805 (1973) (record must demonstrate compelling reason for court not to accept the agreement; court's mere dissatisfaction with the agreement is insufficient).

${ }^{231}$ See supra notes 33-191 and accompanying text.

232 Eisenberg, supra note 135, at 801. Furthermore, he argues "an increase in the complexity of some area of the law may be desirable, if it accurately mirrors the increased complexity of social and economic life." Id.

233 See supra text accompanying notes 43-59. 
of assets or sharp dealing"; then, after a review of the economic circumstances of the parties, they must make a "determination whether under the totality of the circumstances the property division is just and reasonable." ${ }^{234}$ In Wisconsin, too, a court has "the same serious duty to examine carefully [a separation agreement] as it has in making a determination without the aid of such an agreement."235

The necessary scope of, and duty to undertake, judicial review have been particularly well articulated in Missouri, where several cases have held that, after considering the economic circumstances and other relevant evidence, courts have a duty to arrive at a legal conclusion as to whether an agreement is conscionable. ${ }^{238}$ Obviously such a standard of review requires that if the parties do not provide the court with sufficient information to create a record upon which the full picture of the economic circumstances could be drawn, the trial court must request the necessary information sua sponte. ${ }^{237}$

Perhaps the administrative costs argument is more reflective of fundamental doubts concerning the goal of substantive fairness than of genuine fears about the possible costs of imposing and enforcing such a standard. ${ }^{238}$ It would seem, for instance, that the long-range judicial

${ }^{234}$ In re Marriage of Manzo, 659 P.2d 669, 674 (Colo. 1983) (footnote omitted). Colorado has also taken an interesting bifurcated approach to property division and alimony provisions, whereby each is tested separately. The standards under each, moreover, may differ. See Newman v. Newman, 653 P.2d 728 (Colo. 1982) (en banc) (the conscionability review of separation agreements does not extend to an antenuptial agreement relating to property division, but it is an appropriate standard of review for alimony provisions in such an agreement). It is also interesting to note that the unconscionability standard used to review alimony in antenuptial agreements includes a substantive fairness review: the agreement is unconscionable when it results "in a spouse having insufficient property to provide for his reasonable needs." Id. at 735.

${ }^{235}$ Leighton v. Leighton, 81 Wis. 2d 620, 629, 261 N.W.2d 457, 461 (1978) (quoting Miner v. Miner, 10 Wis. 2d 438, 443, 103 N.W.2d 4, 7 (1960)). See also McKinney v. McKinney, 274 S.C. 95, 97, 261 S.E.2d 526, 527 (1980) (duty of court to rule on fairness even when the agreement is plain and unambiguous).

${ }_{2 s e}$ See Block v. Block, 593 S.W.2d 584, 591 (Mo. App. 1980); see also Wilhoit v. Wilhoit, 599 S.W.2d 74, 78 (Mo. App. 1980) (the duty to pass on conscionability is "not a technical impedimentum of decision, but an essential of final judgment"); Turpin v. Turpin, 570 S.W.2d 831,835 (Mo. App. 1978) (simply by accepting an oral agreement, trial court failed to perform its statutorily created duty to examine the relevant factors in determining whether or not the agreement was conscionable).

${ }^{232}$ Arnsperger v. Arnsperger, 624 S.W.2d 87, 89 (Mo. App. 1981); see also Rojas v. Rojas, 595 S.W.2d 729 (Mo. App. 1981) (trial court record, which contained no evidence of husband's income or age, required living expenses, the extent of marital property, condition of wife's health, present value of husband's pension, and other important facts, held insufficient to support the finding that the agreement was not unconscionable).

${ }^{238}$ See, e.g., Arnsperger v. Arnsperger, 624 S.W.2d 87, 89 (Mo. App. 1977) (specifically denying that any unreasonable burden is imposed on either the parties or the court by such requirements; yet the primary concern of this court was the burden of having a full trial over a property settlement). As a practical matter, referees, masters, 
costs, in the form of continuing litigation between the parties, of failure to mandate such a review standard are considerably greater than would be any initial costs of judicial review. ${ }^{238}$ The psychological and economic costs to individuals of litigation over settlement agreements are, of course, greater yet. ${ }^{240}$

Administrative costs would in any case be drastically reduced if courts could develop basic standards by which the essential fairness of agreements submitted to them could be judged. This would imply the additional requirement that parties submit lists of assets, financial statements, and other relevant personal or economic information, since, as noted previously, the agreement itself often fails to reveal the extent of information necessary to make a determination as to its essential fairness. ${ }^{241}$ Assuming that courts were adequately informed of the economic and personal circumstances of the parties, however, and that they could determine fairness norms within some reasonable range, they could single out for intensive scrutiny only those agreements varying substantially from such norms. ${ }^{242} \mathrm{~A}$ lesser degree of scrutiny would nonetheless seem to be necessary to determine those agreements that fell within the norms.

That relatively well-defined standards for determining the essential fairness of settlement agreements cannot be developed is, therefore,

or other administrative officials of the court can undertake a large portion of the review process in many jurisdictions.

230 It is this writer's firm conclusion that no other single issue consumes so many judicial and administrative resources, at both trial and appellate court levels, as disputes over enforcement or modification of settlement agreements after a decree has been entered.

${ }^{210}$ As Professors Mnookin and Kornhauser point out, there are always severe economic and emotional costs for parties in a divorce. Mnookin \& Kornhauser, supra note 17, at 971-72. One of the main functions of private ordering of dissolution consequences is to minimize such costs. Thus to the degree that unfair agreements create antagonisms in litigation they undermine the very purposes they were designed to meet.

241 See supra notes 223-24 and accompanying text.

212 That such "tripping mechanisms" might be developed was suggested by Professors Mnookin and Kornhauser, supra note 17, at 993. Although the authors express considerable doubt that judicial scrutiny is either necessary or feasible, they nonetheless conclude that:

If there remain legitimate fears that many spouses will be taken advantage of through unequal bargaining, and a realistic hope that judicial review of agreements can identify and remedy such cases, then better means should be found to serve such a beneficial function. . . . A better system would define, within a broad range, the norms that should govern divorce agreements and use those norms to identify for intensive judicial scrutiny the cases falling outside what is ordinarily thought reasonable. Cases settled within the normal range would require no prior review at all.

Id. It is, however, difficult to see how a judicial officer could make that initial determination without undertaking at least a limited review of the parties' circumstances. 
the most critical of the objections raised to the thesis of this Article. In an earlier section, unfairness was broadly, and presumptively, defined to encompass those agreements whose benefits or burdens were disproportionate to those that a court would have ordered in the absence of spousal contract. ${ }^{243}$ The issue that must now be confronted is whether there does exist any realistic basis for the suggestion that we can, within a certain practical range, develop more specific and reliable guidelines as to what constitutes fairness.

The presumed lack of any realistic standards by which the substantive fairness of private agreements could be measured has long been a stumbling block to the development of widespread and meaningful fairness reviews. Only a few years ago, Professors Mnookin and Kornhauser pointed out that "existing legal standards governing custody, alimony, child support, and marital property are all striking for their lack of precision."244 The lack of any reliable means to determine what a court would do absent agreement does indeed create, as those authors pointed out, a "bargaining backdrop clouded by uncertainty."24s It would also create great obstacles to the articulation of fairness standards.

Given the rapid decline in the role of fault, however, in both alimony and property division, and the yet more rapid passage of equitable distribution statutes that has occurred even within the past five years, there is good cause to question the degree to which any lack of precision continues realistically to impede the development of fairness norms. This is not to suggest that the result of any individual case would be predictable. The point is rather that, certainly within most states, there exist sufficiently developed standards and principles to determine, within a reasonable range, what courts do when presented with certain factual patterns.

Several factors account for this conclusion. First, although fault remains a "wild card" of some proportions in a few states, it is of negligible or no significance as a factor affecting the distributional consequences of divorce in many others. ${ }^{246}$ In addition, the significance of fault as a source of uncertainty may well have been overestimated. Particularly with property distributions, unequal divisions are much more closely related to factors other than fault, even in those states that con-

${ }^{243}$ See supra text accompanying note 193.

244 Mnookin \& Kornhauser, supra note 17, at 969.

245 Id. It also exposes the parties to the court's "subjective" standard of fairness.

See, e.g., L. WerTzMan, supra note 8 , at 354.

246 See supra note 169. 
sider fault. ${ }^{247}$ Regardless of the role fault continues to play in alimony awards in some states, moreover, alimony itself has an increasingly diminished place in determining the economic consequences of divorce. ${ }^{248}$

Additionally, the impact of fault has been considerably lessened by the increasing acceptance of the economic partnership model that underlies equitable distribution principles. As a New York court recently observed, equitable distribution statutes, in general, are the result of "a growing realization that the marriage relationship is also an economic partnership and that when a marriage ends there should be some comprehensive and fair approach to the economic incidents of divorce."248 And although only a handful of common law states have created a statutory presumption that property should be divided equally, ${ }^{250}$ courtordered dispositions of marital property do tend to be roughly equal, absent extraordinary circumstances.

Equitable distribution statutes also provide an additional means whereby more specific standards, at least for divisions of property, may be developed. Statutes in most states set forth a list of factors that courts must consider in dividing marital property. The five most common of these are, predictably enough, (1) the economic circumstances of each party, (2) the contribution of each to the acquisition of marital property, (3) the duration of the marriage, (4) the age and health of each party, and (5) the desirability of awarding the marital home to the spouse who has custody of minor children. ${ }^{261}$ Assuming that a court has before it the necessary information, therefore, the statutory factors can be matched against that information to create the basis for a determination, or at least a preliminary determination, on the essential fairness of the proposed agreement. Recent decisions in New York ${ }^{\mathbf{2 8 2}}$ and Colorado $^{263}$ have used the statutory factors to create such guidelines. Missouri has gone even further: a leading case holds that'private agreements may not be used to create a means whereby parties can

247 Note, The Discretionary Factor in the Equitable Distribution Act, 60 N.C.L. REv. 1399, 1405-06 (1982).

${ }_{248}$ See Weitzman \& Dixon, The Alimony Myth: Does No-Fault Divorce Make a Difference?, 14 FAM. L.Q. 141, 183 (1980).

${ }^{249}$ Forucci v. Forucci, 83 A.D.2d 169, 171, 443 N.Y.S.2d 1013, 1015 (1981).

230 ARk. STAT. ANN. \& 34-1214(A)(1) (Supp. 1983); N.C. Gen. STAT. § 50-20(c) (Cum. Supp. 1983); Wis. STAT. ANN. $\$ 767.255$ (West 1981). Idaho calls for a substantially equal division unless there are "compelling reasons" for a contrary result, IDAHO CODE § 32-712(1)(a) (Supp. 1981).

251 Note, Property Division and Alimony Awards: A Survey of Statutory Limitations on Judicial Discretion, 50 FordhAM L. REv. 415, 449 (1981); see also UNIF. MARriage AND Divorce ACT \& 307, 9A U.L.A. 142-43 (1973).

282 Tuckman v. Tuckman, 112 Misc. 2d 803, 805-06, 447 N.Y.S.2d 654, 656 (1982)

${ }^{283}$ In re Marriage of Manzo, 659 P.2d 669, 674 \& n.7 (Colo. 1983). 
transgress the statutory standards for divisions of property. ${ }^{254}$

Given, then, the existence of statutory provisions spelling out more clearly than ever before the factors that must be considered in dividing property, the growing acceptance of the economic partnership model, and the decreasing role of alimony and fault, uncertainty about "what a court would do" should no longer act as a bar to the development of reasonable fairness standards and norms. It would hardly seem inappropriate, for example, to suggest that any agreement whereby one spouse received less than thirty-five to forty percent of the marital property should be singled out for special scrutiny. There are, of course, perfectly legitimate reasons for such a disproportionate division in some instances, including a desire to structure a property division as alimony for tax reasons, to compensate one spouse for aiding the other in obtaining a professional degree, or to award the marital home to the custodial spouse. The point is not to preclude parties from contracting in such a fashion but to require that significant disparities in benefits or burdens be explained to the satisfaction of the court before it could approve the agreement. ${ }^{285}$

Similarly, any agreement that obligated a spouse to pay as much as one third of his or her income as maintenance should probably be singled out for scrutiny. Once again, if there are valid reasons for such a provision, no harm would be done to parties or to legal principles by requiring that the record demonstrate such reasons.

That one party was not represented by an attorney should also be a possible trigger for special scrutiny if there is any suggestion of inequality in the distribution of assets. ${ }^{256}$ Although courts have understandably been unwilling to require independent counsel for both parties as a prerequisite to approval of a settlement agreement, ${ }^{287}$ lack of

254 Block v. Block, 593 S.W.2d 584, 591 (Mo. App. 1980). In Turpin v. Turpin, 570 S.W.2d 831 (Mo. App. 1978), the court remanded the case to the trial court for further evidentiary findings. In dicta, the court viewed consideration of the statutory factors as important in determining whether or not an agreement is conscionable. Id. at 835. The Block court turned these dicta into a strict judicial mandate: when a court considers the propriety of a property settlement, "it should consider the factors recited in [the statute] for a division by the court where no agreement exists." Block, 593 S.W.2d at 591 .

${ }_{285} C f$. Goldstein \& Gitter, supra note 17, at 90-93 (in their proposed model statute, the authors argue that the court should approve of a separation agreement only if it is "economically reasonable"); Klarman, supra note 17, at 409 (state should set aside an agreement if it does not guarantee "a minimum standard of support for each of the spouses").

${ }^{258}$ Cf. Gamble, supra note 17, at 733 (in his model rules to govern antenuptial agreements, the author requires that each party be represented by an attorney).

${ }^{257}$ See Brennan v. Brennan, 124 Cal. App. 3d 598, 177 Cal. Rptr. 520 (1981); In re Marriage of Moore, 113 Cal. App. 3d 22, 169 Cal. Rptr. 619 (1980); Bubenik v. Bubenik, 392 So. 2d 943, 944 (Fla. Dist. Ct. App. 1980); Levine v. Levine, 56 N.Y.2d 
representation by only one spouse, in the face of any unfairness of terms, should give rise to grave suspicions of wrongdoing on the part of the represented spouse. ${ }^{208}$ Special judicial scrutiny is also needed where one attorney purports to represent both parties, and there is some inequality in distributional consequences. Courts have never set aside an agreement solely on the basis that one attorney represented both parties, ${ }^{259}$ but the practice is generally not well regarded, and opportunities for overreaching are undeniably present. ${ }^{260}$

There are undoubtedly additional general standards that could be devised and whose violation should trigger special judicial scrutiny. Those already suggested are, after all, little more than common sense. In most instances, however, more specific standards would have to be tailored to the laws of a particular state, particularly to the statutory factors determining property division and alimony. It is sufficient for present purposes to note that the standards suggested here could form the basis for the initial steps in the development of truly effective and efficient means for conducting reviews for the essential fairness of separation agreements.

The final objection to imposition of such standards is that the interest in freedom to contract, and in finality, outweighs any interest in ensuring that the distributional consequences of divorce are fair. ${ }^{281}$ The finality argument is particularly unpersuasive where separation agree-

42, 48-49, 436 N.E.2d 476, 478-79, 451 N.Y.S.2d 26, 28-29 (1982); Whitney v. Seattle-First Nat'l Bank, 90 Wash. 2d 105, 111, 579 P.2d 937, 937-40 (1978) (en banc). ${ }^{258}$ Brennan v. Brennan, 124 Cal. App. 3d 598, 177 Cal. Rptr. 520 (1981) (dissolution of marriage set aside because wife, who was not represented by counsel, was fraudulently convinced by her husband and his attorney that a trial was unnecessary and that she would receive a fair settlement); Moss-Jacober v. Moss, 334 So. 2d 89 (Fla. Dist. Ct. App. 1976) (agreement set aside as unconscionable because of its oppressive terms and because of the husband's lack of legal representation); Sande v. Sande, 83 Idaho 233, 360 P.2d 998 (1961) (the rule-that where agreement is unfair to one party and where there is overreaching by the other party, the court will not enforce the agreement-is especially applicable where first party is ignorant of rights and acted without independent counsel); Arnsperger v. Arnsperger, 624 S.W.2d 87 (Mo. App. 1981) (courts have taken a paternalistic view towards dissolution proceedings, especially when the complainant has not had the representation of independent counsel); Christian v. Christian, 42 N.Y.2d 63, 365 N.E.2d 849, 396 N.Y.S.2d 817 (1977) (even if no actual fraud is shown, a court will intervene if the settlement is manifestly unfair to a spouse because of the other's overreaching, such as when a husband retains an attorney who ostensibly represents the wife).

250 See supra note 226.

${ }^{200}$ Id. In Riley v. Riley, 603 S.W.2d 32, 35 (Mo. 1980), the court observed that there is a "greater readiness on the part of our courts to grant relief to a dissatisfied party . . . who is advised by the other party's attorney."

281 Related to this objection is the desire to escape from any vestiges of paternalism that might exist in traditional family law and that might surface especially when the state through the courts imposes its own fairness standards on the parties. See L. Wertzman, supra note 8 , at xxi, 354-56. 
ments are concerned. Such agreements are commonly executed at most only a few months before a decree of a divorce is entered. Thus a party would rely considerably less on such an agreement than, for example, on an antenuptial agreement. More importantly, only those contracts that fell outside judicial fairness norms would be subject to rejection for merger or incorporation, and only those whose apparently disproportionate terms could not be adequately explained would ever receive such treatment. In addition, the lack of finality that would attach to unfair agreements might have a deterrent effect on the execution of such contracts.

To the degree that the freedom to contract includes freedom to distribute benefits and burdens disproportionately, however, the argument is similarly unpersuasive. For reasons discussed earlier in this Article, separation agreements are different from other types of contracts. ${ }^{262}$ The relationship between the parties, the conditions under which agreements are negotiated, and their long term societal and individual consequences render them appropriate for inclusion in those classes of cases in which, as Professor Eisenberg has argued, "neither fairness nor efficiency supports the application of the bargain principle."263 The fear expressed by one court that imposition of substantive fairness standards would "shake the foundations of separation agreements"264 is poorly founded. Unless we presume that parties negotiate agreements primarily in order to secure unfair results, imposition of such a standard would have no such effect.

\section{CoNCLUSION}

Freedom to contract has been the rallying cry for family law scholars for at least twenty years. The more thoughtful of these writers, however, have not embraced freedom to contract merely as an abstract goal: rather they have sought in contract a means of providing greater fairness-greater justice, if you will-from a system of family laws and principles that long victimized dependent spouses under the guise of protecting them. Disaffection with the application of that system, however, has produced somewhat of an overreaction to the application of special protective principles in family law. Insofar as the "any other contract" approach has been applied to settlement agreements, there is a danger that the baby will be thrown out with the bathwater.

Admittedly, many of the traditional rules governing contracts be-

202 See supra text accompanying notes 29-32.

268 Eisenberg, supra note 135 , at 800.

${ }_{264}$ Davis v. Davis, 268 A.2d 515, 517 (D.C. 1970). 
tween husbands and wives have done considerably more harm than good. Derivation of a duty to disclose from the continuing existence of a confidential relationship is a prime example. To the degree that the law fails to create strict disclosure duties independent of the confidential relationship, it makes a mockery of the husband and wife relationship, the process by which they contract with each other, and the partnership concept of marriage.

The central role of the confidential relationship concept in spousal agreements also effectively manacles many other standard contract doctrines as well, notably the defenses of undue influence and duress. Quite apart from the confidential relationship doctrine, however, standard contract defenses have proved to be inadequate to deal with the unique opportunities for overreaching between spouses. A more flexible and broader definition of unconscionability and expansion of the law of duress could narrow the gap between fairness in process and fairness in result. But such principles are not being applied in family law cases: unconscionability remains tied to defects in process, and the defense of duress remains inapplicable to custody threats and reconciliation promises. Indeed, it seems as if the law has taken the position, as it long did with interspousal violence, that it is acceptable for husbands and wives to do things to each other that neither civil nor criminal law would otherwise tolerate between strangers.

Treating spouses as strangers, however, is not the answer to the inadequacies of the existing system. The unique nature of the husbandwife relationship, the greatly expanded opportunities for deceptive and unfair bargaining practices that stem from that relationship, and the interests of individuals and society that are imperiled by such overreaching are all conditions that render application of classic bargain principles inappropriate in this context. The protective system was a response, albeit a most misguided one, to these conditions; the defective and inequitable results of that system, however, should not be identified with its premise. Husbands and wives are not strangers, and to subject them to contract principles governing negotiations between strangers undermines the very heart of the concept of marriage as a sharing enterprise and ignores the psychological and economic realities of most spousal relationships.

Even with an optimum development and application of contract principles to domestic law, moreover, process is apt to be an inadequate vehicle to secure fair results. The latter can only be reliably produced by a system of meaningful judicial review that, within certain reasonable limits, frankly insists upon substantively fair results. The momentous changes in the substantive law of divorce in recent years have cre- 
ated a much more rational means of determining, and predicting, judicial resolutions of the distributional consequences of divorce in accord with a partnership model. They have thus created the foundation for the development of fairness norms that could provide the means for an effective and efficient system of meaningful júdicial review.

The fundamental problem is that most courts continue to resist the goal of fairness in results. To the degree that such resistance is based upon the alleged impracticability of implementing such a goal, however, a reevaluation would seem in order. To the degree that such resistance is based upon the ideological value of an abstract freedom to contract, it can only be repeated that the marketplace mentality is antithetical to the partnership concept of marriage, the husband-wife relationship, and the interests of society in fair results. 